\title{
Sampling Results, DNAPL Monitoring Well GW-790, Oak Ridge Y-12 Plant, Oak Ridge, Tennessee, First-Third Quarter, FY 1995
}

This document has been approved for release to the public by the Y-12 Plant Technical

Information Officer. Date: 


\section{Oak Ridge Institute for Science and Education (ORISE)}

contributed to the preparation of this document and should not be considered an eligible contractor for its review.

This report has been reproduced directly from the best available copy.

Available to DOE and DOE contractors from the Office of Scientific and Technical Information, P.O. Box 62, Oak Ridge, TN 37831; prices available from 423-576-8401 (fax 423-576-2865).

Available to the public from the National Technical Information Service, U.S. Department of Commerce, 5285 Port Royal Rd., Springfield, VA 22161. 
Energy Systems Environmental Restoration Program

\author{
Sampling Results, DNAPL \\ Monitoring Well GW-790, \\ Oak Ridge Y-12 Plant, \\ Oak Ridge, Tennessee, \\ First-Third Quarter, \\ FY 1995
}

\author{
DISCLAIMER
}

This report was prepared as an account of work sponsored by an agency of the United States Government. Neither the United States Government nor any agency thereof, nor any of their employees, makes any warranty, express or implied, or assumes any legal liability or responsibility for the accuracy, completeness, or usefulness of any information, apparatus, product, or process disclosed, or represents that its use would not infringe privately owned rights. Reference herein to any specific commercial product, process, or service by trade name, trademark, manufacturer, or otherwise does not necessarily constitute or imply its endorsement, recommendation, or favoring by the United States Government or any agency thereof. The views and opinions of authors expressed herein do not necessarily state or reflect those of the United States Government or any agency thereof.

Date Issued-May 1996

\author{
Prepared for the \\ U.S. Department of Energy \\ Office of Environmental Management \\ under budget and reporting code EW 20 \\ Environmental Management Activities at the \\ OAK RIDGE Y-12 PLANT \\ Oak Ridge, Tennessee 37831-8169 \\ managed by \\ LOCKHEED MARTIN ENERGY SYSTEMS, INC. \\ for the \\ U.S. DEPARTMENT OF ENERGY \\ under contract DE-AC05-84OR21400
}

DISTAIBUTION OF THIS DOCURENT IS UNLIMITED 


\section{Author Affiliations}

R. B. Dreier is a member of the Environmental Sciences Division of Oak Ridge National Laboratory, Lockheed Martin Energy Research, Corp., Oak Ridge, Tennessee. A. J. Caldanaro is a participant in the Postgraduate Research Training Program administered by the Oak Ridge Institute for Science and Education, Oak Ridge, Tennessee. 


\section{DISCLAIMER}

Portions of this document may be illegible in electronic image products. Images are produced from the best available original document. 


\section{PREFACE}

This document, Sampling Results, DNAPL Monitoring Well GW-790, First through Third Quarter, FY 1995, was performed under Work Breakdown Structure 1.4.12.1.1.02 (Activity Data Sheet 2312, "Bear Creek Valley"). This document provides the Environmental Restoration Program (ER) with groundwater concentrations for nonradionuclides in the vicinity of the Oak Ridge Y-12 Plant Burial Grounds. This data can be used to determine reference concentrations for intermediate and deep groundwater systems. 


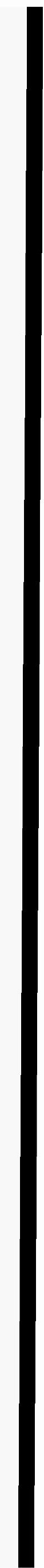




\section{CONTENTS}

\section{Page}

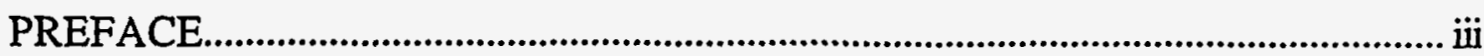

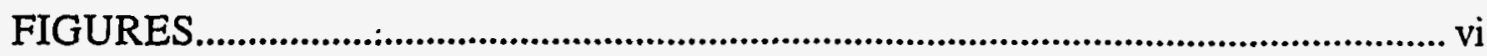

TABLES............................................................................................................. vii

ACKNOWLEDGEMENTS......................................................................................... vii

EXECUTIVE SUMMARY ........................................................................................... ix

LIST OF ACRONYMS AND ABBREVIATIONS....................................................

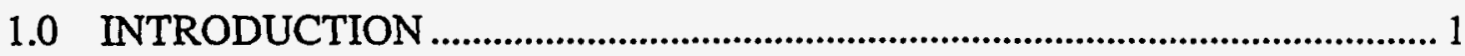

1.1 BACKGROUND AND PURPOSE................................................ 1

1.2 BOREHOLE INFORMATION ............................................................. 3

1.3 MULTIPORT WELL DESCRIPTION.................................................. 3

1.4 GW-790 SAMPLING ZONES..................................................................

2.0 PURGING AND SAMPLING ACTIVITIES ……..............................................

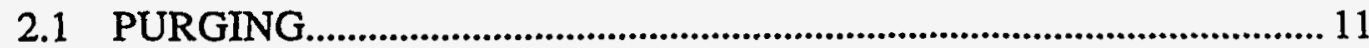

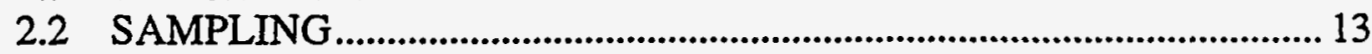

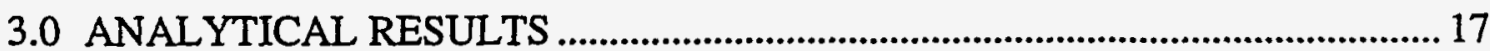

3.1 VOLATILE ORGANIC COMPOUNDS ......................................... 17

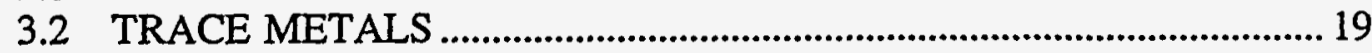

3.3 MAJOR ELEMENT WATER CHEMISTRY ……………........................... 20

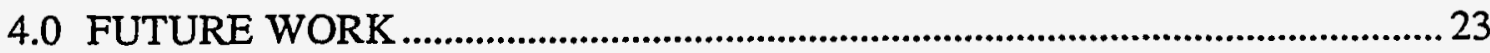

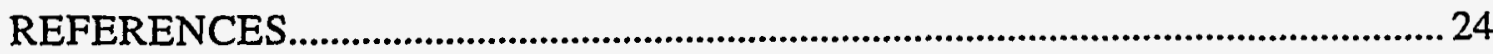

APPENDIX A. TRIP BLANK VOC ANALYTICAL RESULTS ...............................25

APPENDIX B. LABORATORY BLANK VOC ANALYTICAL RESULTS..............27

APPENDIX C. VOC ANALYTICAL RESULTS .......................................................29

APPENDIX D. TRACE METAL ANALYTICAL RESULTS .........................................33

APPENDIX E. MAJOR ANIONS AND CATIONS AND FIELD

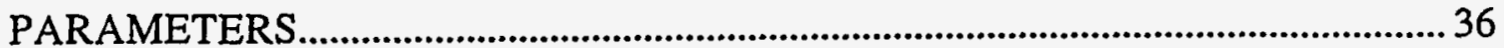

APPENDIX F. CHARGE BALANCE CALCULATIONS............................................. 39 


\section{FIGURES}

Figure

Page

$1 \quad$ Y-12 Burial Grounds location map............................................................. 2

2 Generalized multiport well design............................................................... 6

$3 \quad$ Multiport sampling zones for GW-790 ………................................................ 10

$4 \quad$ Plot of strontium vs. calcium concentrations from GW-790 ................................. 21

5 Piper Diagram of GW-790 Water Chemistry.................................................... 22 


\section{TABLES}

Table

Page

1 GW-790 construction and well design information ...................................... 4

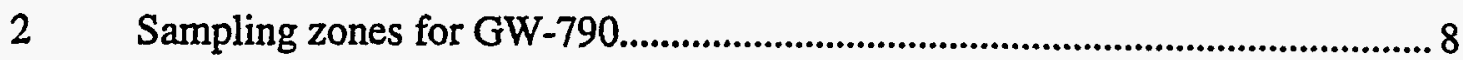

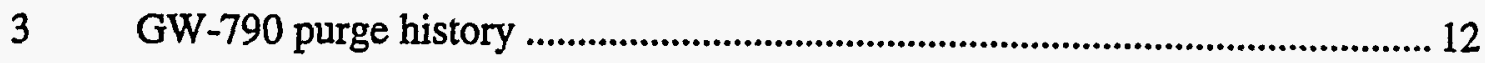

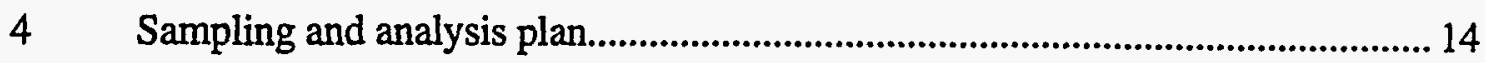

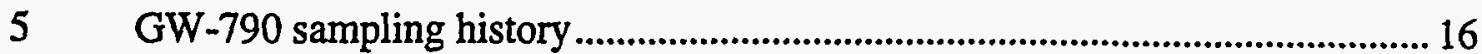

$6 \quad$ GW-790 "detects" from VOC analytical results................................................. 18 


\section{ACKNOWLEDGMENTS}

This report could not have been completed without the help and cooperation from several people. Elizabeth Owens, with help as needed from Kirk Hyder, Jeff Williams and Anthony Garland, took care that all the field work was accomplished efficiently and properly. Y-12 ER organization through John Vanderlan, Helen King and Judy Hodgins provided program direction and financial support.

The authors also wish to thank C. T. Rightmire and D. B. Watson for their constructive review of the report. 


\section{EXECUTIVE SUMMARY}

In January 1990, dense, non aqueous phase liquids (DNAPLs) were discovered at a depth of approximately $274 \mathrm{ft}$. below ground surface along the southern border of the Y-12 Plant Burial Grounds. Immediately after the discovery, an investigation was conducted to assess the occurrence of DNAPL at the site and to make recommendations for further action. Results of the preliminary DNAPL investigation are presented in detail in Haase and King (1990a), and a work plan for assessment and characterization of the DNAPL is presented in Haase and King (1990b). A major task in the work plan calls for the construction and installation of five multiport wells. This report summarizes purging and sampling activities for one of these multiport wells, GW-790, and presents analytical results for GW-790.

To date, each of the eleven sampling zones in GW-790 has been sampled for VOCs, metals and anions. Based on the presence of very low levels of benzene within the middle Nolichucky Shale and the presence of very low levels of TCE in the Maynardville Limestone, it is recommended that VOC monitoring of GW-790 be continued; particularly because TCE is detected in the Maynardville Limestone upgradient from this location. Additional data is required in order to statistically confirm the presence or absence of VOCs through the use of " $J$ " qualifiers. Zones 2, 5, 7 and 10 will be resampled in order to confirm or disprove the presence of nitrate in the deeper portions of the borehole. Purging activities will continue for zones $2,5,7,10$, and 14 to be followed by a second round of sampling. A comparison of the two sets of sampling results will be used to determine the need for a third round of purging. Any additional sampling from zones at the top of the well will be conducted without further purging, unless there is corroborative evidence that the water sample is not representative of the formation. There is a concern that excessive or unnecessary purging of fractured units with low storativity, such as those in GW-790, will mobilize and extend the contaminant plume.

Ongoing and future tasks are directed toward collecting data that will provide information about: (1) the presence or absence of DNAPL or dissolved phase DNAPL and (2) the nature of the groundwater system so that the potential mobility of the dissolved phase plume can be evaluated. With this information we will be prepared to address concerns about the current extent of the contamination, the potential for continued spread of the contamination, and the need, if any, for implementing a remediation strategy. 


\section{LIST OF ACRONYMS AND ABBREVIATIONS}

$\begin{array}{ll}\text { cps } & \text { counts per second } \\ \text { DNAPL } & \text { Dense Non Aqueous Phase Liquid } \\ \text { GC/MS } & \text { Gas Chromatography / Mass Spectroscopy } \\ \text { ICP } & \text { Inductively Coupled Plasma (spectroscopy) } \\ \text { IC } & \text { Ion Chromatography } \\ \text { MCL } & \text { Maximum Contaminant level } \\ \text { mg/L } & \text { milligrams per liter } \\ \text { MP } & \text { Multiport } \\ \text { ND } & \text { Not Detected } \\ \text { OD } & \text { Outer Diameter } \\ \text { psi } & \text { pounds per square inch } \\ \text { PCE } & \text { Tetrachloroethene } \\ \text { TCE } & \text { Trichloroethene } \\ \text { TD } & \text { Total Depth } \\ \text { TDS } & \text { Total Dissolved Solids } \\ \text { VOC } & \text { Volatile Organic Compounds } \\ \text { mg/L } & \text { micrograms per liter }\end{array}$




\subsection{INTRODUCTION}

\subsection{BACKGROUND AND PURPOSE}

In January 1990, dense, non aqueous phase liquids (DNAPLs) were discovered at a depth of approximately $274 \mathrm{ft}$. below ground surface along the southem border of the Y-12 Plant Burial Grounds. Immediately after the discovery, an investigation was conducted to assess the occurrence of DivAfL at the site and to make recommendations for further activin. To date, free-phase DNAPL contamination has been encountered in GW-625 (the discovery well), and is suspected to occur in GW-628 and GW-629 (Fig. 1) (Haase and King, 1990a). In addition, groundwater from GW-117 (Fig. 1) shows levels of volatile organic compounds suggestive of a dissolved contaminant plume. Results of the preliminary DNAPL investigation are presented in detail in Haase and King (1990a), and a work plan for assessment and characterization of the DNAPL is presented in Haase and King (1990b). A major task in the work plan calls for the construction and installation of five multiport wells. These wells (GW-726, GW-727, GW-729, GW-730, GW-730 and GW790) were constructed and instrumented with multiport components from August, 1991 to April, 1993 (Dreier and Caldanaro, 1994). Subsequently, purging and sampling activities were started in each well. This report summarizes purging and sampling activities for GW-790 and presents analytical results for GW-790.

The purpose of the multiport wells is two-fold and addresses specific recommendations made by an independent consultant and previous work (Keuper 1990; Haase and King 1990b):

1) Define the deep and intermediate groundwater flow system within the Bear Creek Burial Ground and contiguous areas. Place special emphasis on defining and characterizing major conductive zones through which most of the groundwater flow may be occurring or through which DNAPL migration may have occurred.

2) Track the dissolved plume from outside inward. With an understanding of the groundwater flow system, determine a nondetect envelope within which all DNAPL and dissolved DNAPL contamination exists. As such, the wells are intended to serve as an early warning system for dissolved plume migration. 


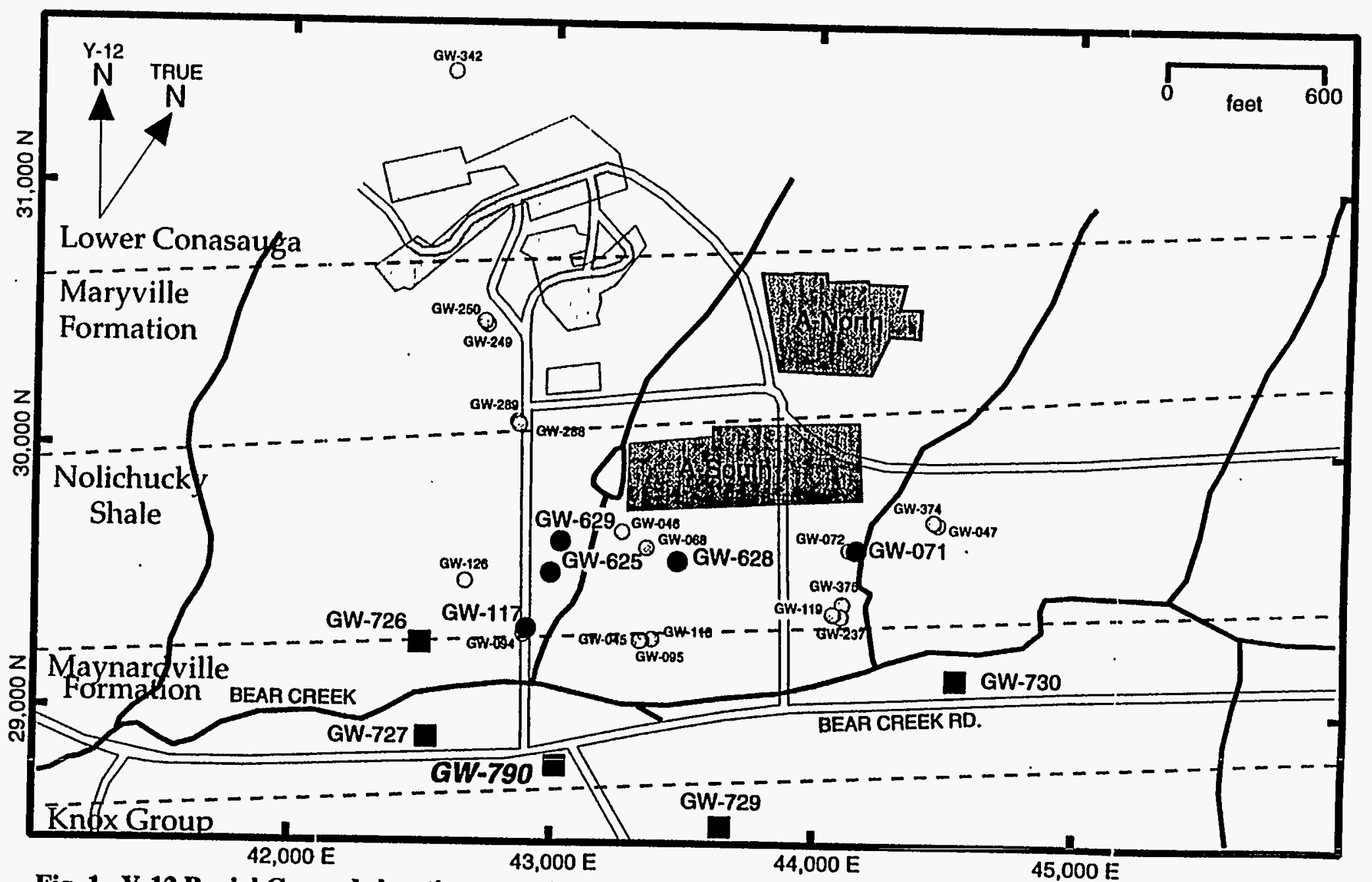

Fig. 1. Y-12 Burial Grounds location map. Dark circles are wells with known DNAPL accumulation or are wells that intercept secondary छroundwater contaminant plumes. Black squares are the five multiport DNAPL investigation wells. GW-790 isi highlighted. Estimated locations of geologic contacts are shown. 
If future technological development provides a feasible method to remove DNAPLs, then data from the multiport wells will provide general knowledge of the DNAPL location. Additionally, the information developed will be necessary to evaluate the effectiveness of the remediation technology (Haase and King, 1990b).

\subsection{BOREHOLE INFORMATION}

The locations of the five multiport wells (GW-726, GW-727, GW-790, GW-729 and GW-730) are shown in Fig. 1. The rationale for well placement is given in Haase and King (1990b) and Dreier and Caldanaro (1994). Well GW-790 is located down dip from the discovery of free-phase DNAPL and downdip from localities where secondary groundwater contaminant plumes associated with DNAPL accumulations have been intercepted by other groundwater monitoring wells. Construction logs for GW-790 are presented in Science Applications International Corporation report, 1993, and the reader is referred to that report for a detailed construction history of the well. Condensed well construction information is presented in Table 1.

\subsection{MULTIPORT WELL DESCRIPTION}

The DNAPL investigation multiport wells use components designed by Westbay Instruments Inc. This system isolates zones of interest from each other by a series of packers fitted about a 1.5 in. diameter PVC (MP) casing (Fig. 2) that acts as an inner standpipe. Within specified sampling zones, fluid pressure data and water samples are collected using specialized probes that are lowered down the inner standpipe to the zones of interest. The probes access the zone through a measurement port coupling in the MP casing. Each sampling zone also contain a pumping port, which is used exclusively for purging. Because the packers isolate each sampling zone from the atmosphere, it is not necessary to purge before each sampling event. Purging is only needed to remove fluids that may have been introduced into the zone during drilling and installation operations.

The sampling zones are isolated from each other by one to two additional zones, called QA zones, containing measurement ports, from which only fluid pressure data are collected (Fig. 2). The zones provide added assurance that the sampling zones are isolated from each other. Although, it is possible to obtain water samples from these zones, the zones do not contain pumping ports and it is not possible to purge these intervals. Thus these zones have limited value for characterizing water chemistry. 
Table 1. GW-790 construction and well design information BOREHOLE CONSTRUCTION

\begin{tabular}{|l|r|}
\hline $\begin{array}{l}\text { Surface Casing (ft bgs) } \\
\text { Total Depth (ft bgs) }\end{array}$ & $212.5^{* *}$ \\
\hline
\end{tabular}

\begin{tabular}{|c|c|c|c|c|c|}
\hline \multicolumn{3}{|c|}{ SURVEY COORDINATES } & \multicolumn{3}{|c|}{ ELEVATIONS ( $\mathrm{ft}$ amsl) } \\
\hline \multicolumn{2}{|c|}{$\begin{array}{l}\text { Grid System } \\
\text { Northing } \\
\text { Easting }\end{array}$} & \multicolumn{3}{|c|}{\begin{tabular}{r|l} 
Y-12 & Ground surface \\
28676 & Top of concrete pad \\
43041.1 & Top of steel casing \\
& Thn of MP casing \\
\end{tabular}} & $\begin{array}{r}909 . \\
\text { NA } \\
911.6 \\
911.5 \\
\end{array}$ \\
\hline \multicolumn{6}{|c|}{ MULTIPORT DESIGN } \\
\hline \multicolumn{2}{|c|}{ COMPLETION ZONE } & \multicolumn{3}{|c|}{ MEASUREMENT PORT } & PUMPING PORT \\
\hline $\begin{array}{c}\text { Zone } \\
\text { Number }\end{array}$ & $\begin{array}{c}\text { Interval } \\
\text { depth } \\
\text { bgs (ft) } \\
\end{array}$ & $\begin{array}{c}\text { Port } \\
\text { depth } \\
\text { bgs (ft) }\end{array}$ & $\begin{array}{c}\text { True Port } \\
\text { depth } \\
\text { from TOMP (ft) }\end{array}$ & $\begin{array}{c}\begin{array}{c}\text { Elevation } \\
\text { (amsl) } \\
\text { (ft) }\end{array} \\
\end{array}$ & $\begin{array}{c}\text { Port } \\
\text { depth } \\
\text { bgs (ft) }\end{array}$ \\
\hline 1 & $1036-1041$ & 1036 & 1035.7 & -124.2 & \\
\hline 2 & $1021-1031$ & 1026 & 1025.7 & -114.2 & 1031 \\
\hline 3 & $1006-1016$ & 1006 & 1005.7 & -94.2 & \\
\hline 4 & $982-1001$ & 982 & 982.7 & -71.2 & \\
\hline 5 & $967-977$ & 972 & 972.7 & -61.2 & 977 \\
\hline 6 & $947-962$ & 947 & 947.7 & -36.2 & \\
\hline 7 & $932-942$ & 937 & 937.7 & -26.2 & 942 \\
\hline 8 & $912-927$ & 912 & 912.7 & -1.2 & \\
\hline 9 & $885-907$ & 885 & 885.7 & 25.8 & \\
\hline 10 & $870-880$ & 875 & 875.7 & 35.8 & 880 \\
\hline 11 & $850-865$ & 850 & 850.7 & 60.8 & \\
\hline 12 & $830-845$ & 830 & 830.7 & 80.8 & \\
\hline 13 & 808-825 & 808 & 808.7 & 102.8 & \\
\hline 14 & $793-803$ & 798 & 798.7 & 112.8 & 803 \\
\hline 15 & $768-788$ & 768 & 768.7 & 142.8 & \\
\hline 16 & $743-763$ & 743 & 743.7 & 167.8 & \\
\hline 17 & $713-738$ & 723 & 723.7 & 187.8 & \\
\hline 18 & $703-708$ & 703 & 703.7 & 207.8 & \\
\hline 19 & $676-698$ & 686 & 686.7 & 224.8 & 698 \\
\hline 20 & $656-671$ & 656 & 656.8 & 254.8 & \\
\hline 21 & $631-651$ & 631 & 631.8 & 279.7 & \\
\hline 22 & $596-626$ & 596 & 596.8 & 314.7 & \\
\hline 23 & $576-591$ & 586 & 586.8 & 324.7 & 591 \\
\hline \multicolumn{6}{|c|}{$\begin{array}{l}\text { NOTE: all depths except for "true depth bgs" are measured along the borehole } \\
\text { with no correction for borehole deviation. } \\
\text { NOTE: samples are only collected from those zones with both measurement and pumping ports, } \\
\text { which are marked in bold. } \\
\text { NOTE: Only depths and not elevations are provided for the pumping ports because samples } \\
\text { are not collected from these ports. Samples are collected from measurement ports. } \\
\text { * MP = Westbay Multiport Casing, ags = above ground surface. } \\
\text { * bgs = below ground surface, amsl = above mean sea level. } \\
\text { *TOMP = Top of MP casing } \\
\text { ** casing is groured to } 40.0^{\prime} \text { rather than } 212.5 \mathrm{ft} \text {. }\end{array}$} \\
\hline
\end{tabular}


Table 1. cont.

\begin{tabular}{|c|c|c|c|c|c|}
\hline \multicolumn{6}{|c|}{$\frac{\text { MULTIPORT DESIGN }}{\text { COMPLETION ZONE }}$} \\
\hline \multicolumn{2}{|c|}{ COMPLETION ZONE } & \multicolumn{3}{|c|}{ MEASUREMENT PORT } & PUMPING PORT \\
\hline $\begin{array}{c}\text { Zone } \\
\text { Number }\end{array}$ & $\begin{array}{c}\text { Interval } \\
\text { depth } \\
\text { bgs (ft) } \\
\end{array}$ & $\begin{array}{c}\text { Port } \\
\text { depth } \\
\text { bgs (ft) }\end{array}$ & $\begin{array}{c}\begin{array}{c}\text { True Port } \\
\text { depth } \\
\text { from TOMP (ft) }\end{array} \\
\end{array}$ & $\begin{array}{c}\text { Elevation } \\
\text { (amsl) } \\
(\mathrm{ft})\end{array}$ & \begin{tabular}{|c|}
$\begin{array}{c}\text { Port } \\
\text { depth } \\
\text { bgs (ft) }\end{array}$ \\
\end{tabular} \\
\hline 24 & $546-571$ & 546 & 546.86 & 364.65 & \\
\hline 25 & $516-541$ & 516 & 516.89 & 394.62 & \\
\hline 26 & $486-511$ & 486 & 486.91 & 424.60 & \\
\hline 27 & $461-481$ & $46 i$ & 4061.92 & 449.59 & \\
\hline 28 & $437-456$ & 437 & 437.93 & 473.58 & \\
\hline 29 & $422-432$ & 427 & 427.94 & 483.57 & 432 \\
\hline 30 & $392-417$ & 392 & 392.95 & 518.56 & \\
\hline 31 & $358-387$ & 358 & 359.96 & 551.55 & \\
\hline 32 & 343-353 & 348 & 349.96 & 561.55 & 353 \\
\hline 33 & $318-338$ & 318 & 319.97 & 591.54 & \\
\hline 34 & $292-313$ & 292 & 293.97 & 617.54 & \\
\hline 35 & $277-287$ & 282 & 283.98 & 627.53 & 287 \\
\hline 36 & $260-272$ & 260 & 261.98 & 649.53 & \\
\hline 37 & $235-255$ & 235 & 236.99 & 674.52 & \\
\hline 38 & $220-230$ & 220 & 221.99 & 689.52 & \\
\hline 39 & 198-215 & 203 & 204.99 & 706.52 & 215 \\
\hline \multicolumn{6}{|c|}{$\begin{array}{l}\text { NOTE: all depths except for "true depth bgs" are measured along the borehole } \\
\text { with no correction for borehole deviation. } \\
\text { NOTE: samples are only collected from those zones with both measurement and pumping ports. } \\
\text { which are marked in bold. } \\
\text { NOTE: Only depths and not elevations are provided for the pumping ports because samples } \\
\text { are not collected from these ports. Samples are collected from measurement ports. } \\
\text { * MP = Westbay Multiport Casing, ags = above ground surface. } \\
\text { * bgs = below ground surface, amsl = above mean sea level. } \\
\text { *TOMP = Top of MP casing } \\
\text { ** casing is grouted to } 40.0^{\prime} \text { rather than } 212.5 \mathrm{ft} \text {. }\end{array}$} \\
\hline
\end{tabular}




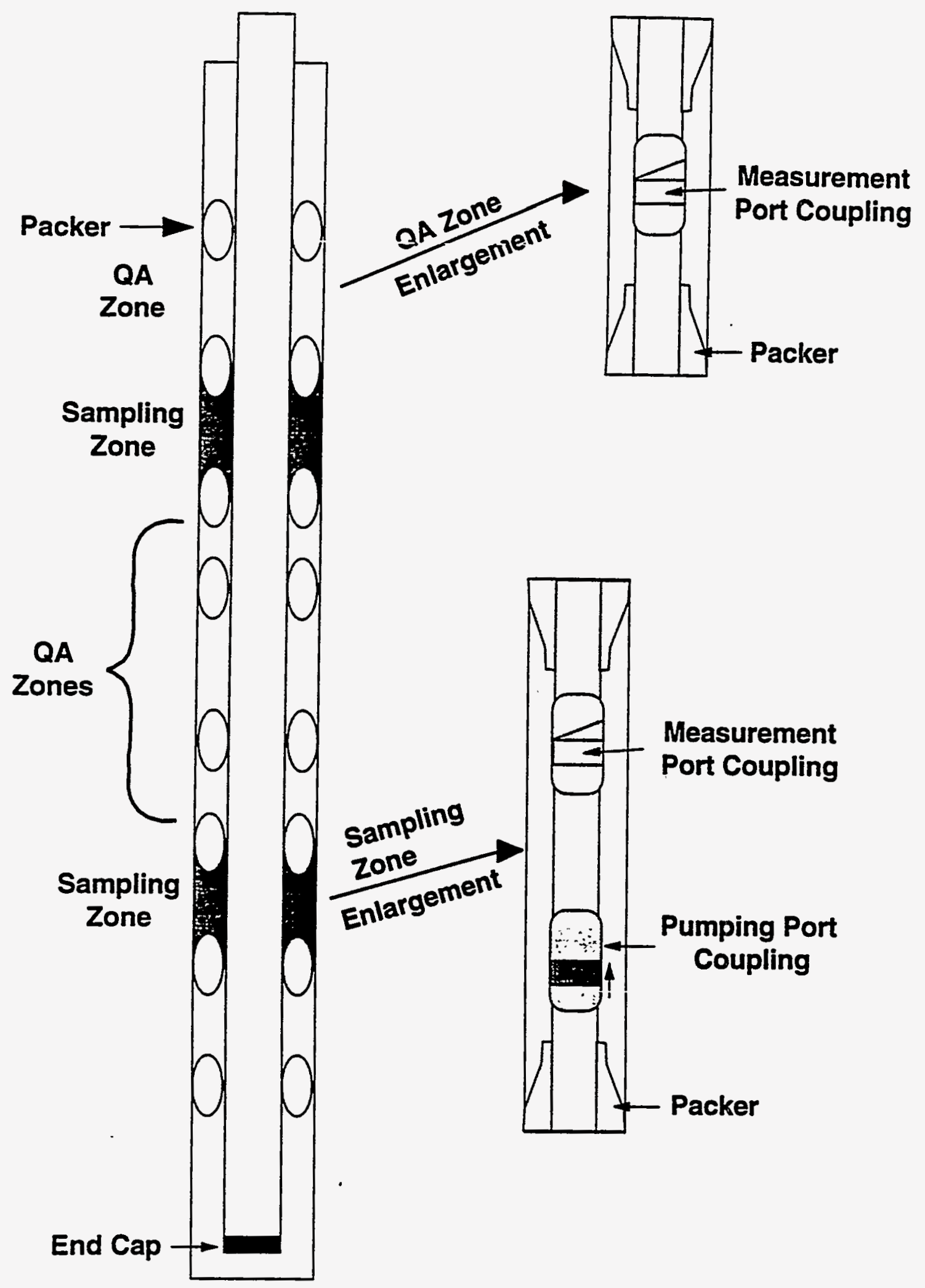

Figure 2. Generalized multiport well design. 


\subsection{GW-790 SAMPLING ZONES}

The multiport completion design for GW-790 is shown in Table 1. On the basis of core samples, geophysical logs and flowmeter results, 11 sampling zones, 10-to-22 ft. long, were selected from GW-790. The reader is referred to Dreier and Caldanaro (1994) for a more detailed description of the technical rationale and component design for each of the DNAPL investigation wells. Table 2 specifically lists criteria for choosing sampling zones and is taken verbatim from Dreier and Caldanaro (1994). The installation history for GW790 is documented in Westbay Instruments Inc. (1993).

The zones were chosen to sample at least one of the following features, in order of priority. (1) fluids from potential zones of DNAPL migration, (2) fluids from hydraulically conductive fractures or fracture zones, (3) potential changes in fluid chemistry with depth, (4) fluids that show water chemistry signatures associated with a particular rock type, (5) fluids that may show water chemistry correlations between wells, and (6) matrix fluids with long residence times. In general, criteria 3,4 and 5 can be achieved by having a relatively regular vertical distribution of sampling zones. The spacing between most zones is less than $100 \mathrm{ft}$, and spacing less than $80 \mathrm{ft}$ is common in potential DNAPL regions.

The stratigraphic positions of the eleven sampling zones in GW-790 are shown in Fig. 3. A zone of potential DNAPL migration, shown as a broad shaded portion, (Dreier and Caldanaro, 1994) was identified before the well was instrumented with Westbay components and is based on stratigraphic correlation with GW-625, GW-628, GW-629 and GW-117. This zone is the oolitic-rich limestone interval that defines the base of the middle Nolichucky Shale (Hatcher et.al, 1992) and is sampled by zones 7 and 10. In addition, two more zones were installed in the underlying strata in order to investigate the potential for migration of DNAPL into the lower Nolichucky Shale. 
Table 2. Sampling zones for GW-790a

\begin{tabular}{|c|c|c|c|c|}
\hline $\begin{array}{c}\text { Multiport } \\
\text { zone }^{b}\end{array}$ & $\begin{array}{l}\text { Depth } \\
\text { (ft. })^{c, d}\end{array}$ & $\begin{array}{c}\text { Samp. port } \\
\text { depth }(\mathrm{ft} .)^{c, d}\end{array}$ & Purpose & Logs/Core \\
\hline 39 & $\begin{array}{l}40-215 \\
(40-213)\end{array}$ & $\begin{array}{l}203 \\
(203)\end{array}$ & $\begin{array}{l}\text { Sample karst feature for Exit } \\
\text { Pathway program }\end{array}$ & $\begin{array}{l}\text { core: Cave 200.7-211.6 } \\
\text { logs: No fractures identified. } \\
\text { stratigraphy: Maynardville Limestone zone } 3 / 4\end{array}$ \\
\hline 35 & $\begin{array}{l}277-287 \\
(277-287)\end{array}$ & $\begin{array}{r}282 \\
(282)\end{array}$ & $\begin{array}{l}\text { Sample karst feature for Exit } \\
\text { Pathway program }\end{array}$ & $\begin{array}{l}\text { core: Cavity, 282.3-282.5 } \\
\text { logs: Temperature 276-283'; sonic } \\
\text { stratigraphy: Maynardville Limestone zone } 3 / 4\end{array}$ \\
\hline 32 & $\begin{array}{l}343-353 \\
(343-353)\end{array}$ & $\begin{array}{l}348 \\
(348)\end{array}$ & Sample fracture & $\begin{array}{l}\text { core: Fracture; large euhedral calcite ctystals, 348.9- } \\
\text { 349.3' } \\
\text { logs: Fluid resistivity, } 346.5-350.0^{\prime} ; \text { sonic } \\
\text { stratigraphy: upper Nolichucky Shale }\end{array}$ \\
\hline 29 & $\begin{array}{l}422-432 \\
(421-431)\end{array}$ & $\begin{array}{l}427 \\
(426)\end{array}$ & Sample fracture & $\begin{array}{l}\text { core: Granular calcite crystals, } 426.8^{\prime} \\
\text { logs: Temperature, } 428.5^{\prime} \text {; fluid resistivity, } 427-430.5^{\prime} \text {. } \\
\text { stratigraphy: upper Nolichucky Shale }\end{array}$ \\
\hline 23 & $\begin{array}{l}576-591 \\
(580-590)\end{array}$ & $\begin{array}{r}586 \\
(585)\end{array}$ & Sample potential conductive zone. & $\begin{array}{l}\text { core: Broken shale, } 583.1-588.1^{\prime} \\
\text { logs: Fluid resistivity, } 5866-589.5^{\prime} \text {; sonic } \\
\text { stratigraphy: middle Nolichucky Shale }\end{array}$ \\
\hline 19 & $\begin{array}{l}676-698 \\
(675-690)\end{array}$ & $\begin{array}{r}687 \\
(686)\end{array}$ & Sample potential conductive zone. & $\begin{array}{l}\text { core: Shale broken and crumbly } 678-679.1,680.0- \\
681.4^{\prime}, 685.5-585.8^{\prime} \text { shale extremely soft, broken, } \\
\text { crumbly and clayeey, water seeps out when pressure } \\
\text { applied; broken shale } 696.7-697.4 \\
\text { logs: Fluid resistivity, } 680-699^{\prime} \text {-- very pronounced at } \\
684-686.5^{\prime} \text {; sonic anomaly (but not a depth of fluid } \\
\text { resisitivity response) } \\
\text { stratigraphy: middle Nolichucky Shale }\end{array}$ \\
\hline 14 & $\begin{array}{l}793-803 \\
(792-802)\end{array}$ & $\begin{array}{c}797 \\
(798)\end{array}$ & Sample potential fracture & $\begin{array}{l}\text { core: Fracture, small euhedral calcite crystals, 797.1' } \\
\text { logs: geophysical logs not available } \\
\text { stratigraphy: middle Nolichucky Shale }\end{array}$ \\
\hline
\end{tabular}


Table 2 (cont.)

\begin{tabular}{|c|c|c|l|l|}
\hline 10 & $\begin{array}{l}870-880 \\
(869-879)\end{array}$ & $\begin{array}{c}875 \\
(874)\end{array}$ & $\begin{array}{l}\text { Sample potential zone of DNAPL } \\
\text { migration at base of middle } \\
\text { Nolichucky Shale. }\end{array}$ & $\begin{array}{l}\text { core: Fracture, coated with white calcite, uneven fit } \\
\text { between both fracture surfaces 874.3' } \\
\text { logs: geophysical logs not available } \\
\text { stratigraphy: base of middle Nolichucky Shale }\end{array}$ \\
\hline 7 & $\begin{array}{c}932-942 \\
(931-941)\end{array}$ & $\begin{array}{c}937 \\
(936)\end{array}$ & $\begin{array}{l}\text { Sample potential zone of DNAPL } \\
\text { migration at base of middle } \\
\text { Nolichucky Shale. }\end{array}$ & $\begin{array}{l}\text { core: Fracture coated with smooth and granular calcite. } \\
\text { Small pyrite crystals show oxidation, 936.7'. } \\
\text { logs: geophysical logs not available } \\
\text { stratigraphy: base of middle Nolichucky Shale }\end{array}$ \\
\hline 5 & $\begin{array}{c}967-977 \\
(966-976)\end{array}$ & $\begin{array}{c}97 \cdot 2 \\
(971)\end{array}$ & Sample potential fracture & $\begin{array}{l}\text { core: Fracture, incipient, Fractures, open (broken } \\
\text { during drilling, costed with smooth calcite, 971.1'. } \\
\text { logs: geophysical logs not available } \\
\text { stratigraphy: lower Nolichucky Shale }\end{array}$ \\
\hline 2 & $\begin{array}{c}1021- \\
1031\end{array}$ & $\begin{array}{c}1026 \\
(1026)\end{array}$ & Sample potential conductive zone. & $\begin{array}{l}\text { core: Shale, broken, 1024.5-1027.2' } \\
\text { logs: geophysical logs not available } \\
\text { stratigraphy: lower Nolichucky Shale }\end{array}$ \\
\hline
\end{tabular}

arepeated vertbatim from Dreier and Caldanaro (1994), Table 12.

bMultiport zone number.

cDepth measured from ground surface, not corrected for borehole deviation

dParentheses denote planned depth. Other number is correct downhole depth. 


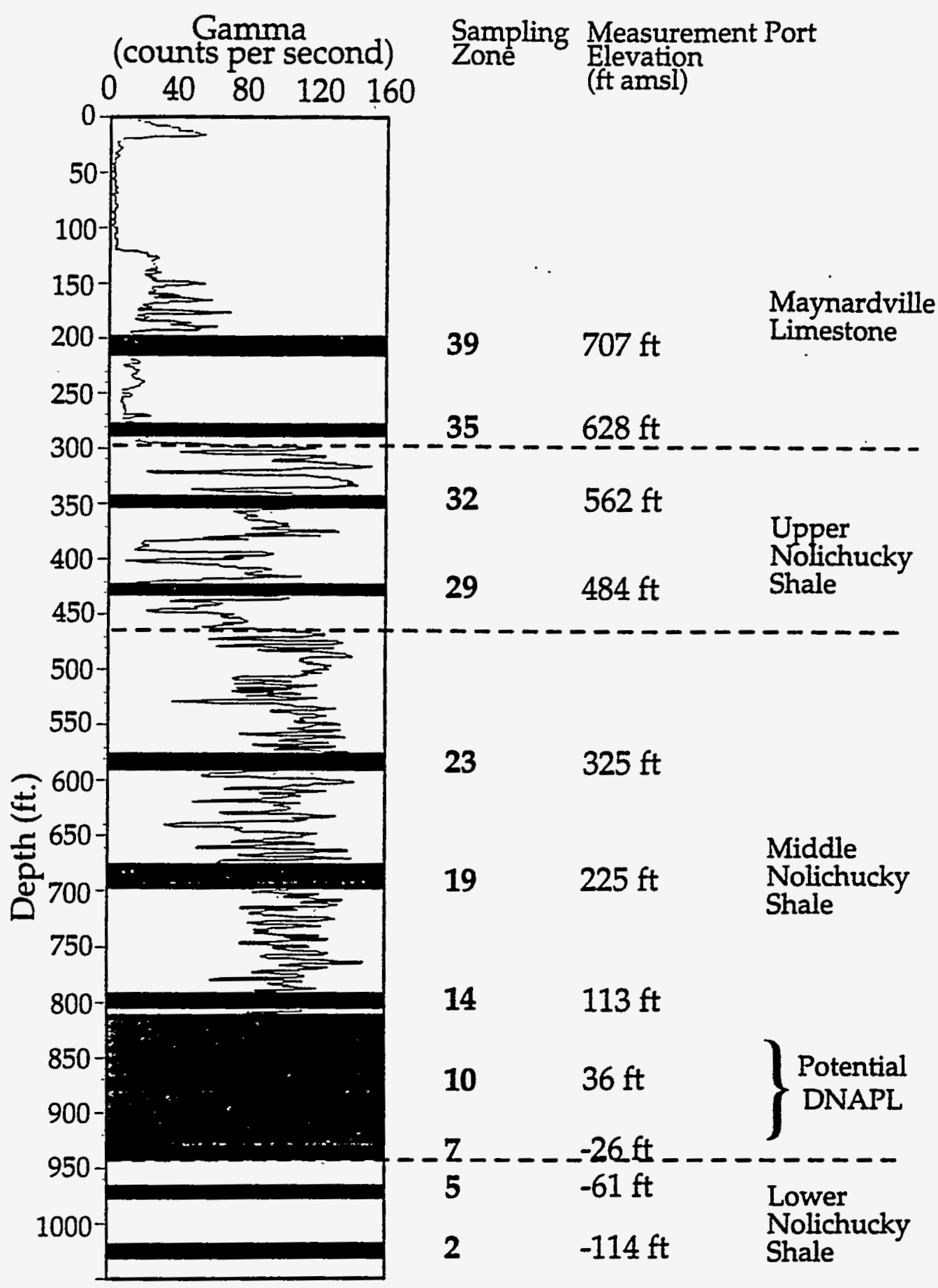

Figure 3. Multiport sampling zones for GW-790. The region marked Potential DNAPL is not meant to imply that DNAPL occurs in this interval at this location. Rather, this zone correlates to the same stratigraphic interval at shallower depths up dip where DNAPL was visually observed and where dissolved phase plumes were identified. The shaded portion above zone 39 represents the true thickness of the sampling zone. Because of difficulties encountered during installation, it was not possible to seat the upper packer of this zone. 


\subsection{PURGING AND SAMPLING ACTIVITIES}

\subsection{PURGING}

Initial purging of the sample zones in GW-790 began in August, 1994, several months after hydraulic heads had stabilized from multiport installation, and continued though April, 1995 (Table 3). During purging, an appropriate volume of water is extracted from the inner standpipe so that the hydraulic head in the standpipe is lower than the hydraulic head in the sampling zone. This induces water to flow from the formation and annular space through the open purge port into the inner standpipe. Recommended purge volumes are calculated at three times the annular volume of the sampling zone (Table 3). The rate at which this volume is produced is a function of the rock permeability and can vary considerably. In particular, it was found that very low permeability zones could take several months or longer to produce the requisite volumes. Because of this, purging procedures were modified so that sampling activities could fit into a reasonable scheduling framework. At present, each zone is purged for one month or until the recommended volume of water is produced, whichever occurs first. The zone is then sampled. If the zone does not produce enough water during the first round of purging, purging is continued for another month, to be followed by a second round of sampling. Additional purging requirements will be determined on a case-by-case basis, but in general, the removal of one annular volume for very low permeability zones at the base of the borehole may be considered adequate in the future.

Of eleven sampling zones in GW-790, five produced the requisite three annular volumes within a month of purging. These zones (zones 19,23, 29, 32, 35 and 39) are in the upper portion of the well and may indicate that permeability decreases with increasing depth. In addition, although zone 39 at the top of the well did not produce 3 volumes of water, the relatively low production is not related to low permeability. Rather, this zone is unusually large because of problems encountered during installation (Dreier and Caldanaro, 1994), and the increased thickness was not taken into account in calculating purge volumes. Note (Table 3) that zone39 easily produced almost 50 gals in one day. The zone includes several karst features (Dreier and Caldanaro, 1994) and should be self-purging because of the large flux of groundwater that is transmitted through cavities. Of the remaining 5 zones at the base of the well, zone 2 produced at least one annular volume. Zones 5, 7, 10 and 15 were open for approximately one month and did not produce one annular volume. However, they did produced aproximately between 0.3 and 0.8 annular volumes in one month. Therefore it is anticipated that with one or two more rounds of month-long purging, these zones will be able to produce at least one annular volume. 
Table 3. GW-790 purge history

\begin{tabular}{|c|c|c|c|c|c|c|c|}
\hline Zone & $\begin{array}{c}\text { Packed-off } \\
\text { Sampling } \\
\text { Zone Height } \\
\text { (ft) }\end{array}$ & $\begin{array}{l}\text { Recom. } \\
\text { purge } \\
\text { volume } \\
\text { (gals)* }\end{array}$ & $\begin{array}{l}\text { Ist Purge } \\
\text { Date } \\
\text { Opened }\end{array}$ & $\begin{array}{l}\text { Ist Purge } \\
\text { Date } \\
\text { Closed }\end{array}$ & $\begin{array}{c}\text { Produced } \\
\text { purge vol. } \\
\text { (gals) }\end{array}$ & $\begin{array}{c}\text { Total } \\
\text { no. } \\
\text { annular } \\
\text { vols. }\end{array}$ & \begin{tabular}{|c|} 
Difference \\
of actual $(-)$ \\
recom. \\
(gals)
\end{tabular} \\
\hline 2 & 11 & 14 & $3 / 7 / 95$ & $4 / 10 / 95$ & 5.3 & $\overline{1.1}$ & -8.6 \\
\hline 5 & 11 & 14 & $1 / 31 / 95$ & $3 / 7 / 95$ & 1.6 & 0.3 & -12.3 \\
\hline 7 & 11 & 14 & $12 / 20 / 94$ & $1 / 31 / 95$ & 1.7 & 0.4 & -12.2 \\
\hline 10 & 11 & 14 & $11 / 23 / 94$ & $12 / 20 / 94$ & 3.8 & 0.8 & -10.1 \\
\hline 14 & 11 & 14 & $10 / 27 / 94$ & $11 / 23 / 94$ & 2.5 & 0.5 & -11.4 \\
\hline 19 & 23 & 29 & $9 / 7 / 94$ & $10 / 5 / 94$ & 30.0 & 3.1 & 1.0 \\
\hline 23 & 16 & 20 & $10 / 5 / 94$ & $10 / 27 / 94$ & 24.7 & 3.7 & 4.5 \\
\hline 29 & 11 & 14 & $9 / 1 / 94$ & $9 / 1 / 94$ & 30.4 & 6.6 & 16.5 \\
\hline 32 & 11 & 14 & $8 / 30 / 94$ & $9 / 1 / 94$ & 23.7 & 5.1 & 9.8 \\
\hline 35 & 11 & 14 & $8 / 30 / 94$ & $8 / 30 / 94$ & 30.6 & 6.6 & 16.7 \\
\hline 39 & 176 & 222 & $8 / 29 / 94$ & $8 / 29 / 94$ & 47.7 & 0.6 & -174.1 \\
\hline \multicolumn{8}{|c|}{$\begin{array}{l}\text { H } \\
\text { * Zones that require additional purging are shown in bold } \\
\text { * PURGE VOLUME CALCULATION: } \\
\text { Recommended purge volume = } 3 \text { annular volumes } \\
3.7 \text { " diameter borehole and } 1.81 \text { " OD MP casing } \\
\text { "= } 0.42 \text { gal/ft for one annular volume or } 1.26 \text { gal/ft for three annular volumes" } \\
\text { Zones shown in bold did not produce the requisite three annular volumes of formation wate }\end{array}$} \\
\hline
\end{tabular}




\subsection{SAMPLING}

Samples are collected in two evacuated (under vacuum) stainless steel $250 \mathrm{ml}$ sample bottles that are attached in tandem and threaded to a sampling probe. The sample bottles are lowered to the desired zone and water is extracted through the measurement port valve. All equipment is designed specifically for and dedicated to Westbay type multiport wells. Additional information on Westbay-specific sampling procedures is in the Westbay Operation Manuals, which are available from the authors of this report.

The field sampling protocol is given in Table 4. Initially, each zone is sampled for anions, metals, VOCs and field parameters ( $\mathrm{pH}$, specific conductance and temperature). The normal suite of anion analysis includes $\mathrm{Cl}, \mathrm{Fl}, \mathrm{NO}_{3}$, and $\mathrm{SO}_{4}$. If the specific conductance is greater than 2000 umho/cm, $\mathrm{Br}$ is added to the suite since its concentration may be above detection at elevated specific conductance levels. Additional sampling events are based on initial analytical results and are determined at the discretion of the project manager or project technical lead.

Using two sample bottles, a maximum sample volume of $500 \mathrm{ml}$ can be obtained each time bottles are lowered to a port (a sample run) (Table 4). In general, either two or three runs are needed to collect the required sample volume, depending on the desired analysis. Two different protocols are used based on the suspected permeability of the sampling zone. For high to moderate permeability zones, the first run is used to collect field parameters and to rinse the sample bottles with formation water. If both inorganic (major and trace elements) and organic constituents are being sampled, the second run is used for the major and trace inorganic water samples and the third run is used for the VOC sample. VOCs are collected last to maximize the number of sample bottle rinses with formation water.

As of February, 1995, several types of control samples are collected during sampling: (1) A trip blank sample is obtained each time a VOC sample is collected; (2) A field blank is prepared for $10 \%$ of the VOC sampling events; (3) A duplicate sample is collected for $10 \%$ of all sampling events. (4) An equipment rinsate, consisting of the final DI water rinse from the inside of the sample bottle, is collected for $10 \%$ of all sampling events. Zones 2, 5, 7 and 10 were sampled after February 1995, but these samples were not part of the $10 \%$ population used for duplicates or equipment rinsates. 
Table 4. Sampling and analysis plan.

High to Moderate Permeability

\begin{tabular}{|c|c|c|c|c|c|c|c|c|}
\hline $\begin{array}{r}\text { Sa } \\
\text { Run No. }\end{array}$ & $\begin{array}{l}\text { mple } \\
\text { Bottle No. }\end{array}$ & Parameter & $\begin{array}{l}\text { Container } \\
\text { Type }\end{array}$ & $\begin{array}{c}\text { Volume } \\
\text { (ml) }\end{array}$ & Filtered & Preservative & Procedure No. & $\begin{array}{l}\text { Analytical } \\
\text { Method }\end{array}$ \\
\hline 1 & 1 & $\mathrm{pH}$ & N/A & $<250$ & YES & N/A & EPA-1.50.1 & $\mathrm{pH}$ meter \\
\hline 1 & 1 & Specific Conductance & N/A & $<250$ & YES & N/A & EPA-120.1 & onductivity meter \\
\hline 1 & 1 & Temperature & N/A & $<250$ & YES & N/A & EPA-170.1 & thermometer \\
\hline 1 & 2 & rinsate/discard & N/A & N/A & YES & N/A & N/A & N/A \\
\hline 2 & 1 & Metals & Plastic & 100 & YES & HNO3 $(<2 \mathrm{pH})$ & EPA- 6010 & $\overline{I C P}$ \\
\hline 2 & 1 & Anions ( $\left.\mathrm{Er} \mathrm{r}^{*}, \mathrm{Cl}, \mathrm{Fl}, \mathrm{NO}, \mathrm{SO} 4\right)$ & Plastic & 100 & YES & NONE & EPA-300.0 & IC \\
\hline 2 & 2 & Alkalinity & Plastic & 100 & YES & NONE & EPA-310.1 & titration \\
\hline 3 & 1 & VOC & Amber/Glass & $40 \times 2$ & $\mathrm{NO}$ & NONE & OLMO & GC/MS \\
\hline
\end{tabular}

Low Permeability**

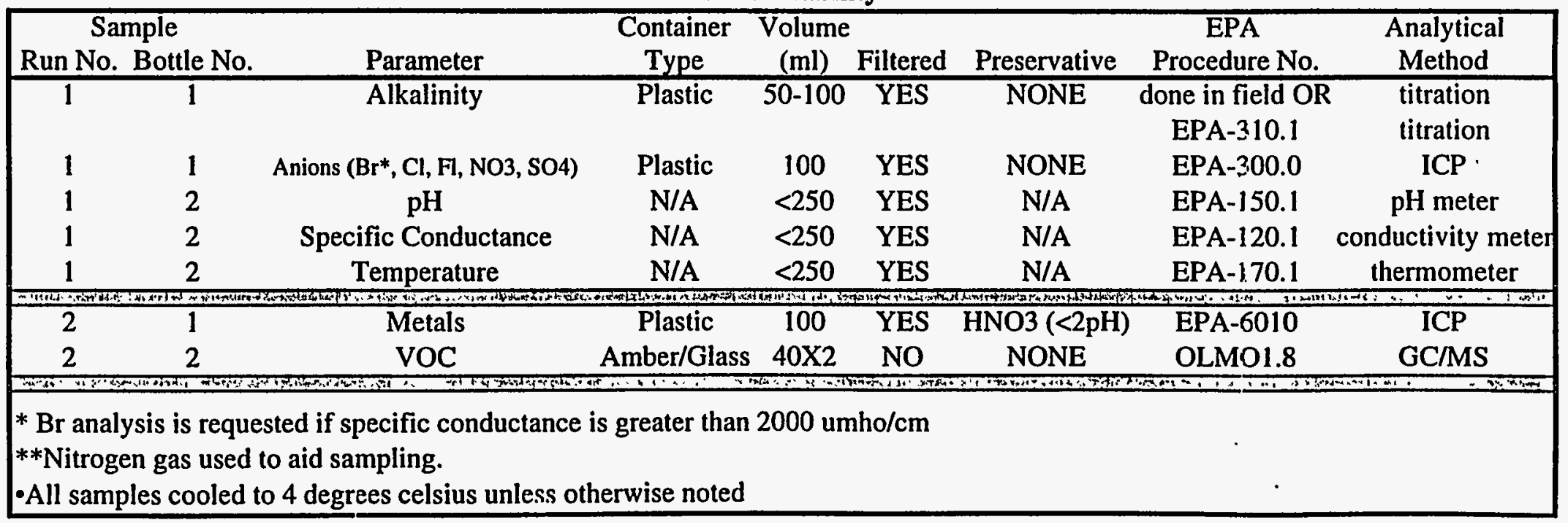


A common occurance with sampling low permeability zones is that the O-ring seal is compromised around the measurement port. This can be determined by monitoring the water level in the MP casing. A drop in water level is attributed to water from the MP casing that moves past the O-rings, through the sample probe, and into the sample bottles. The resultant sample is a mixture of water from the annular space and from the MP casing. If this happens, the zone is treated as a "low permeability zone" and both the sampling order and collection method is modified (Table 4). Field parameters will be collected from the first run second (lower) bottle. This tottle will have the least amount of rinsing with formation waters. Alkalinity and anions will be collected from the first run first (upper) bottle. The remainder of the sample will be collected from the second run. As before, VOCs will not be sampled from the first run to assure that the sample bottle is rinsed with formation water. If a O-ring seal is broken during sampling, water collected from the first run, second bottle will be used to re-rinse the bottle.

In low-permeability zones, the seal around the measurement port may be broken because: (1) the zone could not produce enough water to maintain a sufficient fluid pressure; and (2) there is a large pressure differential between the sample bottles, the MP casing water and the formation water. The purpose of the modified sampling collection procedure is to reduce the pressure differential between the sample bottles and the pressure in the MP casing. This is accomplished by pressurizing the sample bottles with inert nitrogen gas between 50 and 110 psi. This pressure is well below the fluid pressure in the MP casing and the formation, yet is sufficient enough to maintain the integrity of the seal around the mesurement port valve allowing water to be drawn from the formation. To date, this method has been successful when used in low permeability zones.

The sampling history for GW-790 is given in Table 5. No sampling zones show the low permeability characteristics mentioned above. This is in constrast with results from other multiport monitoring wells in the area (GW-727 and GW-730) where there is an excellent correspondance between the zones that showed sampling difficulties and the zones that did not produce the requisite purge water volumes in four weeks of purging. 
Table 5. GW-790 sampling history.

\begin{tabular}{|c|c|c|c|}
\hline Zone & Date & Parameters & Comments \\
\hline$\overline{2}$ & $4 / 23 / 95$ & $\begin{array}{c}\text { VOC } \\
\text { Metals, Anions, Alk. } \\
\text { field parameters }\end{array}$ & Bromide included with Anions \\
\hline 5 & $4 / 23 / 95$ & $\begin{array}{c}\text { VOC } \\
\text { Metals, Anions, Alk. } \\
\text { field parameters }\end{array}$ & Bromide included with Anions \\
\hline 7 & $4 / 23 / 95$ & $\begin{array}{l}\text { VOC } \\
\text { Metals, Anions, Alk. } \\
\text { field parameters }\end{array}$ & $\begin{array}{l}\text { Bromide included with Anions } \\
\text { B. }\end{array}$ \\
\hline 10 & $4 / 23 / 95$ & $\begin{array}{c}\text { VOC } \\
\text { Metals, Anions, Alk. } \\
\text { field parameters }\end{array}$ & Bromide included with Anions \\
\hline 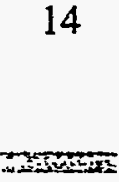 & $12 / 13 / 94$ & $\begin{array}{c}\text { VOC } \\
\text { Metals, Anions, Alk. } \\
\text { field parameters }\end{array}$ & Bromide included with Anions \\
\hline 19 & $12 / 13 / 94$ & $\begin{array}{c}\text { VOC } \\
\text { Metals, Anions, Alk. } \\
\text { field parameters }\end{array}$ & Bromide included with Anions \\
\hline 23 & $12 / 14 / 94$ & $\begin{array}{c}\text { VOC } \\
\text { Metals, Anions, Alk. } \\
\text { field parameters }\end{array}$ & \\
\hline 29 & $12 / 14 / 94$ & $\begin{array}{l}\text { VOC } \\
\text { Metals, Anions, Alk. } \\
\text { field parameters }\end{array}$ & \\
\hline 32 & $12 / 14 / 94$ & $\begin{array}{c}\text { VOC } \\
\text { Metals, Anions, Alk. } \\
\text { field parameters }\end{array}$ & \\
\hline 35 & $12 / 14 / 94$ & $\begin{array}{c}\text { VOC } \\
\text { Metals, Anions, Alk. } \\
\text { field parameters }\end{array}$ & Water is very muddy \\
\hline 39 & $12 / 14 / 94$ & $\begin{array}{l}\text { VOC } \\
\text { Metals, Anions, Alk. } \\
\text { field parameters }\end{array}$ & Water is very gray \\
\hline
\end{tabular}




\subsection{ANALYTICAL RESULTS}

\subsection{VOLATILE ORGANIC COMPOUNDS}

A sample was collected for VOC analysis for each zone (Table 5). Trip blanks were collected on 12/13/94 and 4/23/95 and their results are listed in Appendix A. No VOCs were detected in the trip blanks (Appendix A). Laboratory blank data are given in Appendix $\bar{B}$ and show a detect with a " $\mathrm{J"}$ qualifier for acetone on 4/25/95. "J" quadifiers indicate that the stated $\mathrm{VOC}$ levels are estimated at values that are below the detection limit. In addition, the 4/25/95 laboratory blank sample had a detect for 2-Butanone of $13.0 \mu \mathrm{g} / \mathrm{L}$.

VOC results from the sample zones are presented in Appendix $C$ and a list of 12 VOCs detects is given in Table 6. Ten of the twelve detectable values are flagged with a "J" qualifier and represent low $(1.0-10.0 \mu \mathrm{g} / \mathrm{L})$ but discemible responses from the analytical instrumentation. Of the 12 VOC detects, 3 corresponded to detects in the lab or trip blanks associated with the sample. The remaining detects with " $\mathrm{J}$ " qualifiers include one for styrene in zone 32, benzene is observed in all of the zones below and including zone 23 , and trichloreoethene (TCE) is observed in zone 35. Based on results from GW-727 (Dreier and Caldanaro in prep), and GW-730 (Dreier and Caldanaro in prep), benzene appears to be a common VOC detected in the low-permeability, deeper portions of the DNAPL monitoring wells and has been observed in the upper, middle and lower Nolichucky Shale as well as the Maryville Formation. It is possible the pervasive presence of benzene in trace amounts is due to the occurance of natural hydrocarbons. However, benzene is a VOC is concern because it does occur in more than $5 \%$ of wells associated with the Y-12. Burial Grounds (HSW, 1994). Although TCE is observed in very low estimated quantities $(1 \mathrm{mg} / \mathrm{L})$ in zone 35 , TCE is a VOC contaminant of concem in Bear Creek Valley that may be coming from an upstream source in the Maynardville Limestone. Zone 35 samples a hydraulically active fracture/cavity at the base of the Maynardville Limestone (Table 2). 
Table 6. GW-790 VOC analytical results that are tagged with a " $J$ " qualifier.

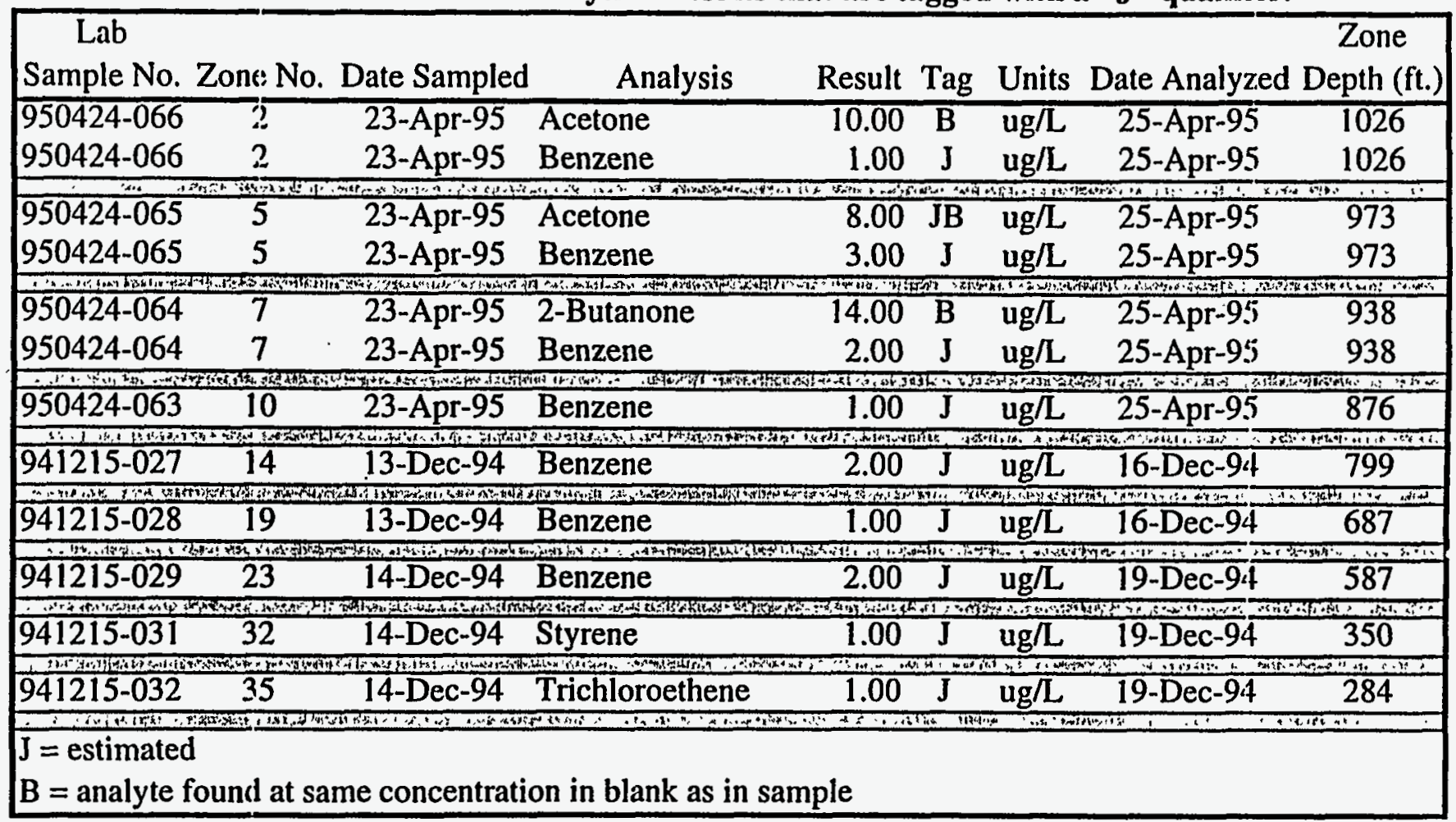




\subsection{TRACE METALS}

One sample per zone was collected for metal analysis (Table 5). Metal concentrations were determined by ICP spectroscopy and are listed in Appendix D. Available background screening levels listed in the GWQAR for Bear Creek Valley (HSW, 1994) are also listed in Appendix D, and detection limits are given as less than $(<)$ values in Appendix D. Samples from zones 19 and below were diluted because of high ionic concentrations. All of these zones showed TDS values greater than $3000 \mathrm{mg} / \mathrm{L}$ and dilution rates vary as a function of TDS: Zones 14 and 19 (TDS $=3278-4749 \mathrm{mg} / \mathrm{L}$ ) had the least dilution with a dilution factor of 10 , and zone 2 (TDS $=91695 \mathrm{mg} / \mathrm{L}$ ) had the greatest dilution with a dilution factor of 100. As a result of the dilutions, detection limits are raised and some are raised above the background screening levels listed in the GWQAR for Bear Creek Valley (HSW, 1994). This is the case for antimony, beryllium, cadmium, cobalt, lead, molybdenum, thorium, and vanadium (see Appendix D). Note also in Appendix D that the undiluted sample detection limits listed for antimony, lead, molybdenum, and thorium are equivalent to the background screening level for that constituent. Nevertheless, except for molybdenum, all analytical results for constituents with background screening levels below detection limits are below the detection limit, even though concentrations are expected to rise with an increase in TDS (TDS values are listed in Appendix E).

Boron, molybdenum, zinc, iron, manganese, nickel and strontium are above background screening levels for selected zones. The uppermost zones that sample shale-rich lithologies in the Nolichucky Shale (zones 23, 29 and 32)) show boron levels above the background screening levels listed in the GWQAR for Bear Creek Valley (HSW, 1994). Boron values noticeably decrease with increase in depth. and corresponding increase in TDS. Zone 23 shows a molybdenum value above the background screening level, and the remaining lower zones have a detection limit for molybdenum that is above the background screening level. Except for zone 5, all the zones below a depth of $790 \mathrm{ft}$ at the base of the borehole show elevated values of zinc that are above the background screening level of $0.079 \mathrm{mg} / \mathrm{L}$. Iron, manganese and nickel values are above background screening levels for zone 2 . This zone shows the highest TDS value in the borehole (TDS $=91695 \mathrm{mg} / \mathrm{L}$ ). 
Strontium also shows concentrations above the background screening level. The elevated concentrations occur in the deepest 6 zones (zones $2,5,7,10,14,19$ ) where there is also a corresponding increase in TDS. These zones show TDS values greater than $3000 \mathrm{mg} / \mathrm{L}$. The increase in strontium is apparently related to the increase in TDS as is suggested by the proportional correspondence between calcium and strontium concentrations (Fig. 4). Strontium will commonly substitute for calcium because they have the same valence state and a similar ionic radius.

\subsection{MAJOR ELEMENT WATER CHEMISTRY}

Major element water chemistry and field parameters are given in Appendix $E$ and charge balance information is given in Appendix F. Of immediate note is the potential presence of nitrate in zones 2, 5, 7, 10 and 35 . However, it is important to understand that ion chromatography, the analytical technique used for anion analysis, may give misleading results for high chloride waters, which is the water-type for zones 2, 5, 7 and 10 (Fig. 5). These zones will be resampled specifically for nitrate analysis, and an analytical technique will be used where there is no interference between chloride and nitrate values. Zone 35 samples a relatively low TDS mixed cation- $\mathrm{HCO}_{3}$-type water. At present, there is no compelling reason to doubt the presence of nitrate in zone 35 and the source of the nitrate is probably the S-3 Ponds, located to the east of GW-790. Nevertheless, zone 35 will also be resampled to verify the nitrate values.

In general, ionic concentrations are given with two significant digits. Note, however, that for chloride, the significant digits range from two to four. At present, the reason for this change has not been determined and is being investigated with the K-25 Analytical Laboratory. Only seven of the eleven zones showed a charge balance that is less than $10 \%$. The other four zones (zones 2. 5. 7 and 10) had balances between 10\% and 13\%. The reason for the poor charge balances has not been determined. Based on resuits from $G \bar{W}$ 730 (Dreier and Caldanaro, in prep), it is not directly due to high TDS and associated dilution of the sample because GW-730 had several samples with dilution factors of 100 that showed charge balances less than $10 \%$. 


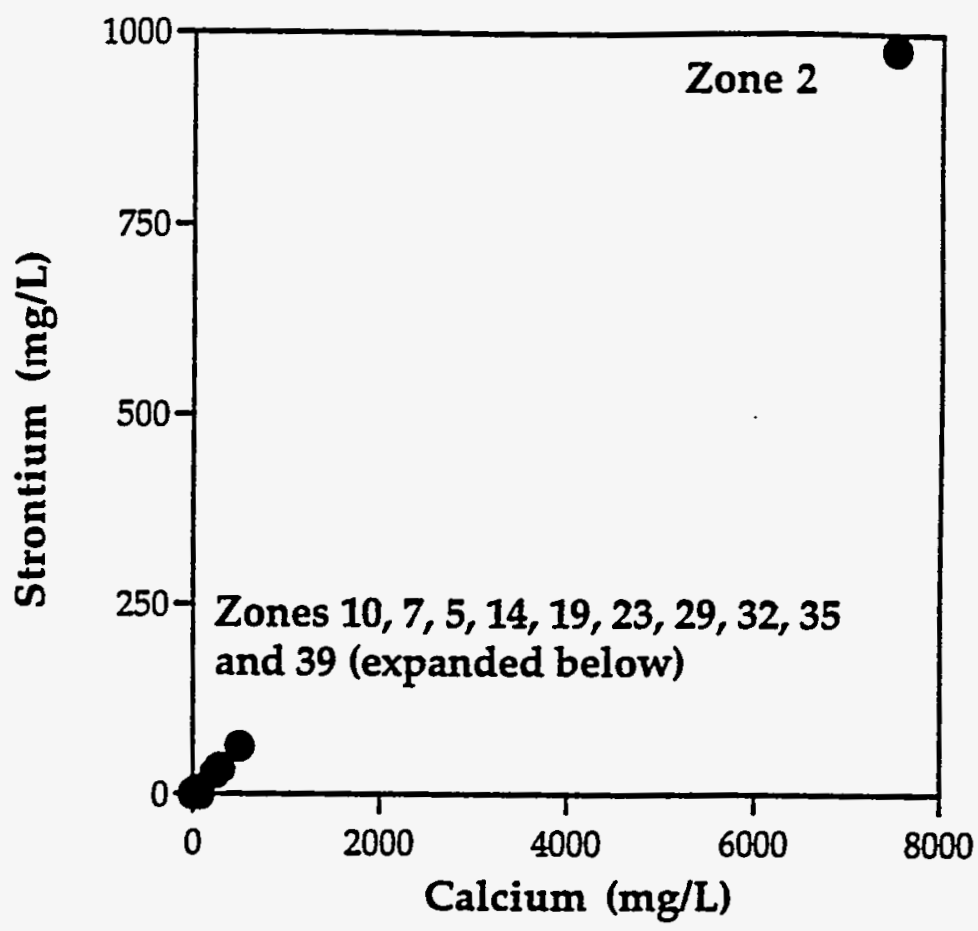

Zone 2

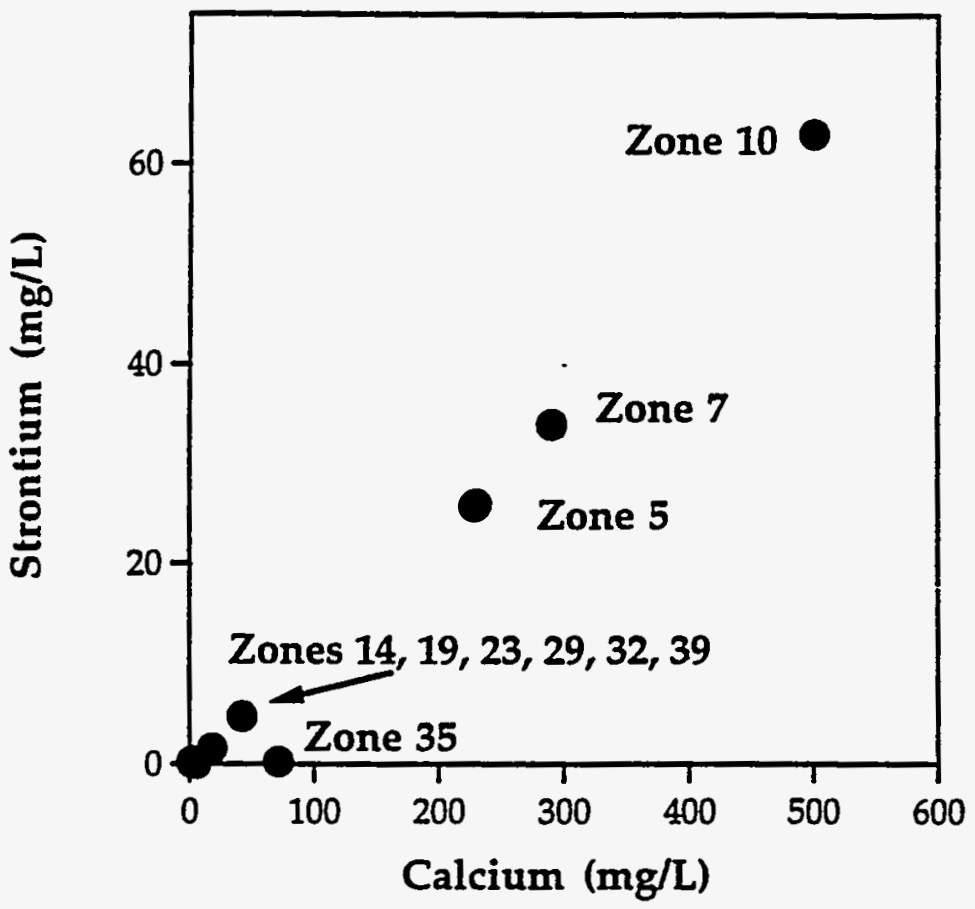

Figure 4. Plot of strontium vs. calcium concentrations from GW-790. The Sr/Ca ratio average is 0.09 and ranges from $0.01-0.13$. 


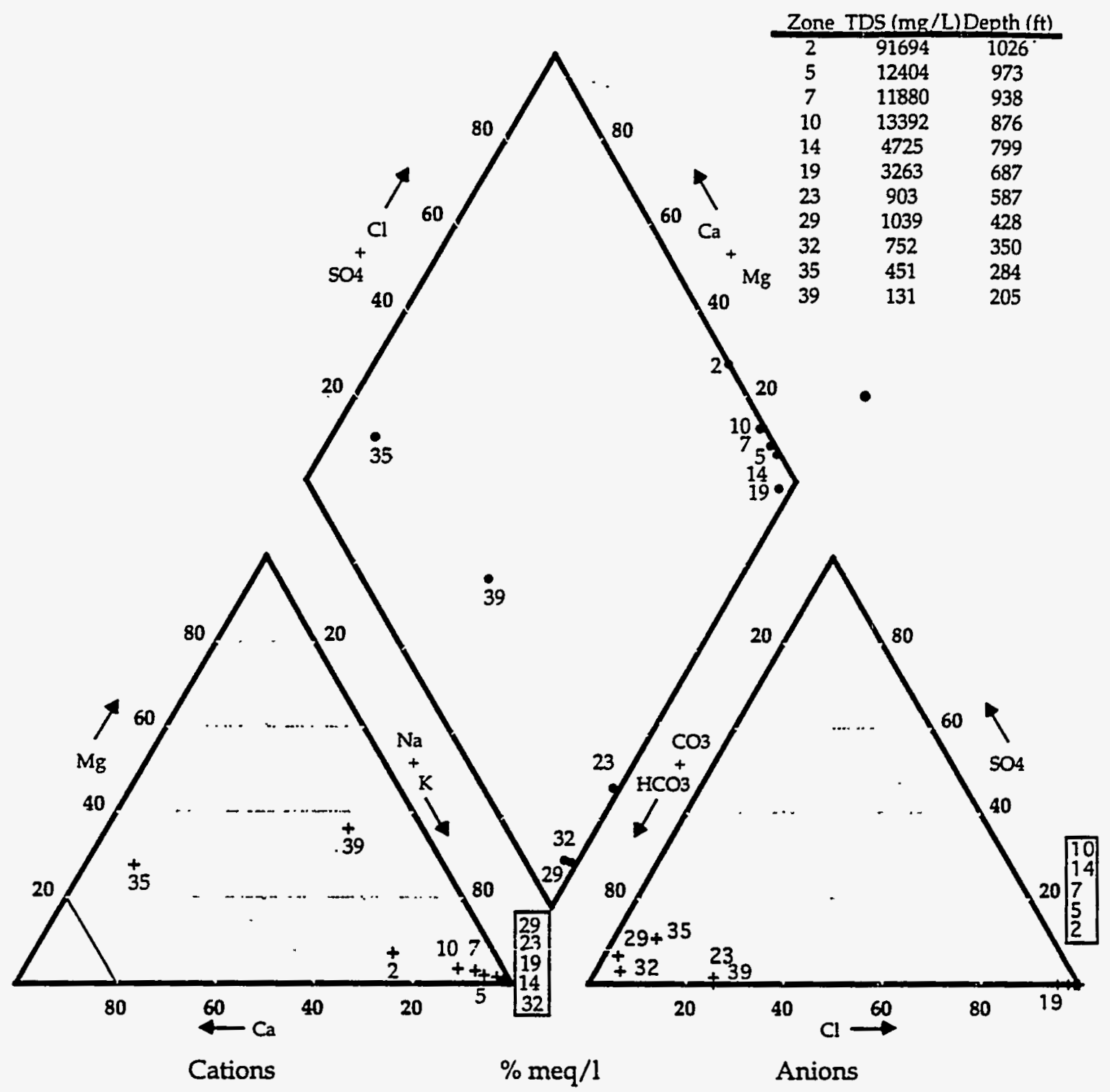

Figure 5. Piper diagram of GW-790 water chemistry. It should be noted that zones $2,5,7$, and 10 were plotted for comparison purposes only. Both had charge balances greater than $\pm 10 \%$. 
Water chemistry types are shown in Fig. 5. There is a systematic change in water type with depth from a relatively shallow mixed cation- $\mathrm{HCO}_{3}$ type water to a deep $\mathrm{Na}-\mathrm{Cl}$ type water. The upper two zones (zones 35 and 39 which show a depth range of $200-300 \mathrm{ft}$ ) sample the Maynardville Limestone and are a $\mathrm{Ca}(\mathrm{Mg})-\mathrm{HCO}_{3}$ to a mixed-cation- $\mathrm{HCO}_{3}$ type water. The upper three zones in the Nolichucky Shale (zones 12, 29 and 32 which show a depth ranges of $300-600$ feet) show a change to a $\mathrm{Na}-\mathrm{HCO}_{3}$ type water. The lowest six zones (zones 2, 5,7,10,14 and 19 which show a depth range of $650-1050 \mathrm{ft}$ ) are a $\mathrm{Na}-\mathrm{Cl}$ type water. The change in water type with depth also corresponds to an approximate increase in TDS with depth (Fig. 5) and in part to those zones that did not produce a sufficient volume of purge water within one month.

\subsection{SUMMARY / FUTURE WORK}

Ongoing and future tasks are directed toward collecting data that will provide information about: (1) the presence or absence of DNAPL or dissolved phase DNAPL and (2) the nature of the groundwater system so that the potential mobility of the dissolved phase plume can be evaluated. With this information we will be prepared to address concerns about the current extent of the contamination, the potential for continued spread of the contamination, and the need, if any, for implementing a remediation strategy.

To date, each of the eleven sampling zones in GW-790 has been sampled for VOCs, metals and anions. Based on the presence of very low levels of benzene within the middle Nolichucky Shale and the presence of very low levels of TCE in the Maynardville Limestone, it is recommended that VOC monitoring of GW-790 be continued; particularly because TCE is detected in the Maynardville Limestone upgradient from this location. Additional data is required in order to statistically confirm the presence or absence of VOCs through the use of "J" qualifiers. Zones 2, 5, 7 and 10 wiii be resampied in order to confirm or disprove the presence of nitrate in the deeper portions of the borehole. Purging activities will continue for zones $2,5,7,10$, and 14 to be followed by a second round of sampling. A comparison of the two sets of sampling results will be used to determine the need for a third round of purging. Any additional sampling from zones at the top of the well will be conducted without further purging, unless there is corroborative evidence that the water sample is not representative of the formation. There is a concern that excessive or unnecessary purging of units with low storativity, such as those in GW-790, will mobilize and extend the contaminant plume. 


\section{REFERENCES}

Dreier, R. B, and A. J. Caldanaro, 1994 . Installation Summary for the DNAPL Characterization Multiport Wells, GW-726, GW-727, GW-729, GW-730 and GW-790. Y/ER-117.

Dreier, R. B, and A. J. Caldanaro, in prep, Sampling Results, DNAPL Monitoring Well GW-727, 1st and 2nd Quarter, FY95. Y/ER-202.

Dreier, R. B, and A. J. Caldanaro, in prep, Sampling Results, DNAPL Monitoring Well GW-730, 1st and 2nd Quarter, FY95. Y/ER-203.

Haase, C. S, and H. L. King, 1990a. Report and preliminary assessment of the occurrence of dense, nonaqueous phase liquids in the Bear Creek Burial Grounds Hazardous Waste Disposal Unit at the Oak Ridge Y-12 Plant. Y/TS-629.

Haase, C. S, and H. L. King, 1990b. "Work Plan for the Preliminary Assessment and Characterization of Dense Nonaqueous-Phase Liquids in the Bear Creek Burial Grounds Hazardous Waste Disposal Unit at the Oak Ridge Y-12 Plant", Y/ER-16.

Hatcher, R. D, Jr., P. J. Lemiszki, R. B. Dreier, R. H. Ketelle, R. R. Lee, D. A. Lietzke, W. M. McMaster, J. L. Foreman, and S.-Y. Lee 1992. Status Report on the Geology of the Oak Ridge Reservation. ORNL/TM-12074. Oak Ridge National Laboratory, Oak Ridge Tennessee, 37831-6285.

HSW Environmental Consultants, Inc. 1994. Calendar Year 1993 Groundwater Quality Assessment for the Bear Creek Hydrogeologic Regime Y-12 Plant, Oak Ridge, Tennessee: 1993 Groundwater Quality Data interpretations and Proposed Program Modifications. Y/SUB/94-EA1/1/P2.

Kueper, R. H. 1990. The occurrence of dense, nonaqueous phase liquids in fractured rock at the Bear Creek Burial Grounds Waste Management Area. Consultant Report submitted to Oak Ridge National Laboratory/Martin Marietta Energy Systems, Inc., on February 23, 1990.

Science Applications International Corporation 1993. Y-12 Environmental Restoration Dense Non-Aqueous Phase Liquid Investigation Field Report: GW-790. Y/ER103.

Westbay Instruments Inc., 1993. Completion report, DNAPL Investigation MP System Wells GW-726, 727, 729, 730 and 790. Consultant Report WB630-93. 
Appendix A

TRIP BLANK VOC ANALYTICAL RESULTS. 
GW-790 Trip Blank VOC Analytical Results.

\begin{tabular}{|l|c|c|}
\hline Sample Number: & $941215-034$ & $950424-067$ \\
Trip Date: & $12 / 13 / 94$ & $4 / 23 / 95$ \\
Date Analyzed: & $12 / 19 / 94$ & $4 / 25 / 95$ \\
Units: & $\mu \mathrm{g} / \mathrm{L}$ & \multicolumn{1}{|c|}{$\mu \mathrm{g} / \mathrm{L}$} \\
\hline 1,1,1-Trichloroethane & $<10.0$ & $<10.0$ \\
1,1,2,2-Tetrachloroethane & $<10.0$ & $<10.0$ \\
1,1,2-Trichloroethane & $<10.0$ & $<10.0$ \\
1,1-Dichloroethane & $<10.0$ & $<10.0$ \\
1,1-Dichloroethene & $<10.0$ & $<10.0$ \\
1,2-Dichloroethane & $<10.0$ & $<10.0$ \\
1,2-Dichloroethene (total) & $<10.0$ & $<10.0$ \\
1,2-Dichloropropane & $<10.0$ & $<10.0$ \\
2-Butanone & $<10.0$ & $<10.0$ \\
2-Hexanone & $<10.0$ & $<10.0$ \\
4-Methyl-2-pentanone & $<10.0$ & $<10.0$ \\
Acetone & $<10.0$ & $<10.0$ \\
Benzene & $<10.0$ & $<10.0$ \\
Bromodichloromethane & $<10.0$ & $<10.0$ \\
Bromoform & $<10.0$ & $<10.0$ \\
Bromomethane & $<10.0$ & $<10.0$ \\
Carbon Disulfide & $<10.0$ & $<10.0$ \\
Carbon Tetrachloride & $<10.0$ & $<10.0$ \\
Chlorobenzene & $<10.0$ & $<10.0$ \\
Chloroethane & $<10.0$ & $<10.0$ \\
Chloroform & $<10.0$ & $<10.0$ \\
Chloromethane & $<10.0$ & $<10.0$ \\
Dibromochloromethane & $<10.0$ & $<10.0$ \\
Ethylbenzene & $<10.0$ & $<10.0$ \\
Methylene Chloride & $<10.0$ & $<10.0$ \\
Styrene & $<10.0$ & $<10.0$ \\
Tetrachloroethene & $<10.0$ & $<10.0$ \\
Toluene & $<10.0$ & $<10.0$ \\
Trichloroethene & $<10.0$ & $<10.0$ \\
Vinyl Acetate & $<10.0$ & $<10.0$ \\
Vinyl Chloride & $<10.0$ & $<10.0$ \\
Xylene (total) & $<10.0$ & $<10.0$ \\
cis-1,3-Dichloropropene & $<10.0$ & $<10.0$ \\
trans-1,3-Dichloropropene & $<10.0$ & $<10.0$ \\
\hline
\end{tabular}


Appendix B

LABORATORY BLANK VOC ANALYTICAL RESULTS. 
GW-790 Laboratory Blank VOC Analytical Results.

\begin{tabular}{|c|c|c|c|}
\hline $\begin{array}{l}\text { Sample Number: } \\
\text { Date Completed: } \\
\text { Units: }\end{array}$ & $\begin{array}{c}941216-092 \\
12 / 16 / 94 \\
\mu \mathrm{g} / \mathrm{L}\end{array}$ & $\begin{array}{c}941219-047 \\
12 / 19 / 94 \\
\mu \mathrm{g} / \mathrm{L}\end{array}$ & $\begin{array}{c}950425-005 \\
4 / 25 / 95 \\
\mu \mathrm{g} / \mathrm{L}\end{array}$ \\
\hline $\begin{array}{l}\text { 1,1,1-Trichloroethane } \\
\text { 1,1,2,2-Tetrachlorocthanc } \\
\text { 1,1,2-Trichloroethane } \\
\text { 1,1-Dichloroethane } \\
\text { 1,1-Dichloroethene } \\
\text { 1,2-Dichloroethane } \\
\text { 1,2-Dichloroethene (total) } \\
\text { 1,2-Dichloropropane } \\
\text { 2-Butanone } \\
\text { 2-Hexanone } \\
\text { 4-Methyl-2-pentanone } \\
\text { Acetone } \\
\text { Benzene } \\
\text { Bromodichloromethane } \\
\text { Bromoform } \\
\text { Bromomethane } \\
\text { Carbon Disulfide } \\
\text { Carbon Tetrachloride } \\
\text { Chlorobenzene } \\
\text { Chloroethane } \\
\text { Chloroform } \\
\text { Chloromethane } \\
\text { Dibromochloromethane } \\
\text { Ethylbenzene } \\
\text { Methylene Chloride } \\
\text { Styrene } \\
\text { Tetrachloroethene } \\
\text { Toluene } \\
\text { Trichloroethene } \\
\text { Vinyl Acetate } \\
\text { Vinyl Chloride } \\
\text { Xylene (total) } \\
\text { cis-1,3-Dichloropropene } \\
\text { trans-1,3-Dichloropropene }\end{array}$ & 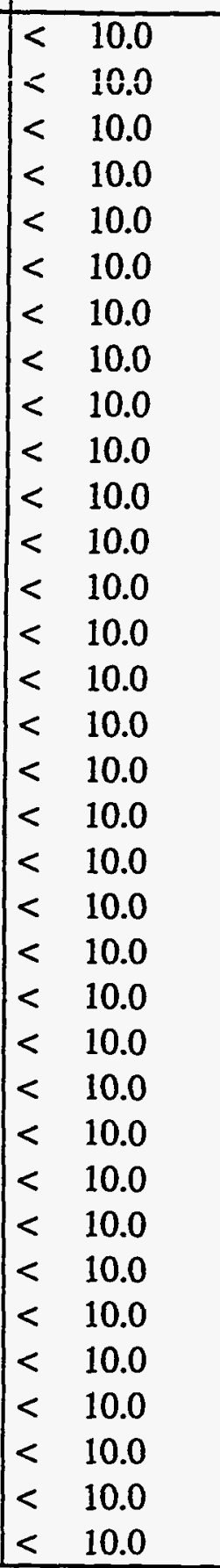 & 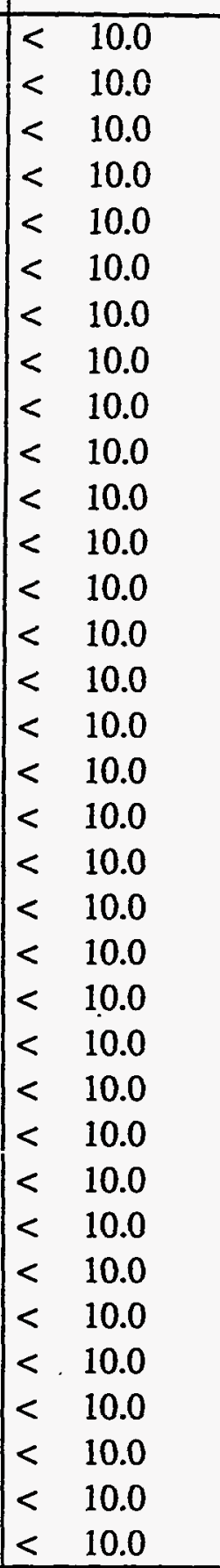 & $\begin{array}{rr} & 10.0 \\
< & 10.0 \\
< & 10.0 \\
< & 10.0 \\
< & 10.0 \\
< & 10.0 \\
< & 10.0 \\
< & 10.0 \\
& 13.0 \\
< & 10.0 \\
< & 10.0 \\
& <9.0 \\
< & 10.0 \\
< & 10.0 \\
< & 10.0 \\
< & 10.0 \\
< & 10.0 \\
< & 10.0 \\
< & 10.0 \\
< & 10.0 \\
< & 10.0 \\
< & 10.0 \\
< & 10.0 \\
< & 10.0 \\
< & 10.0 \\
< & 10.0 \\
< & 10.0 \\
< & 10.0 \\
< & 10.0 \\
< & 10.0 \\
< & 10.0 \\
< & 10.0 \\
< & 10.0 \\
< & 10.0\end{array}$ \\
\hline
\end{tabular}


Appendix C

VOC ANALYTICAL RESULTS. 
GW-790 VOC Analytical Results

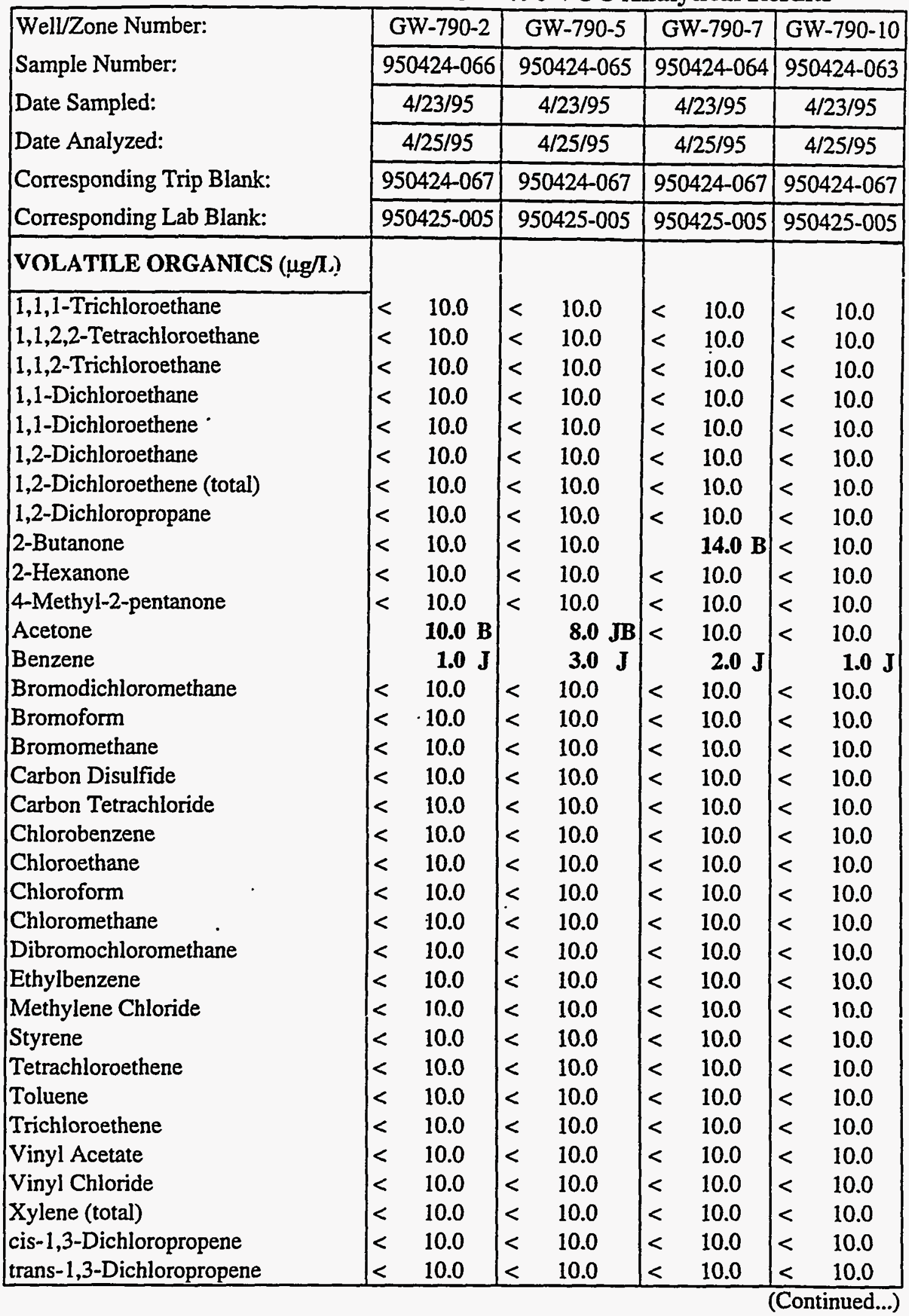


GW-790 VOC Analytical Results

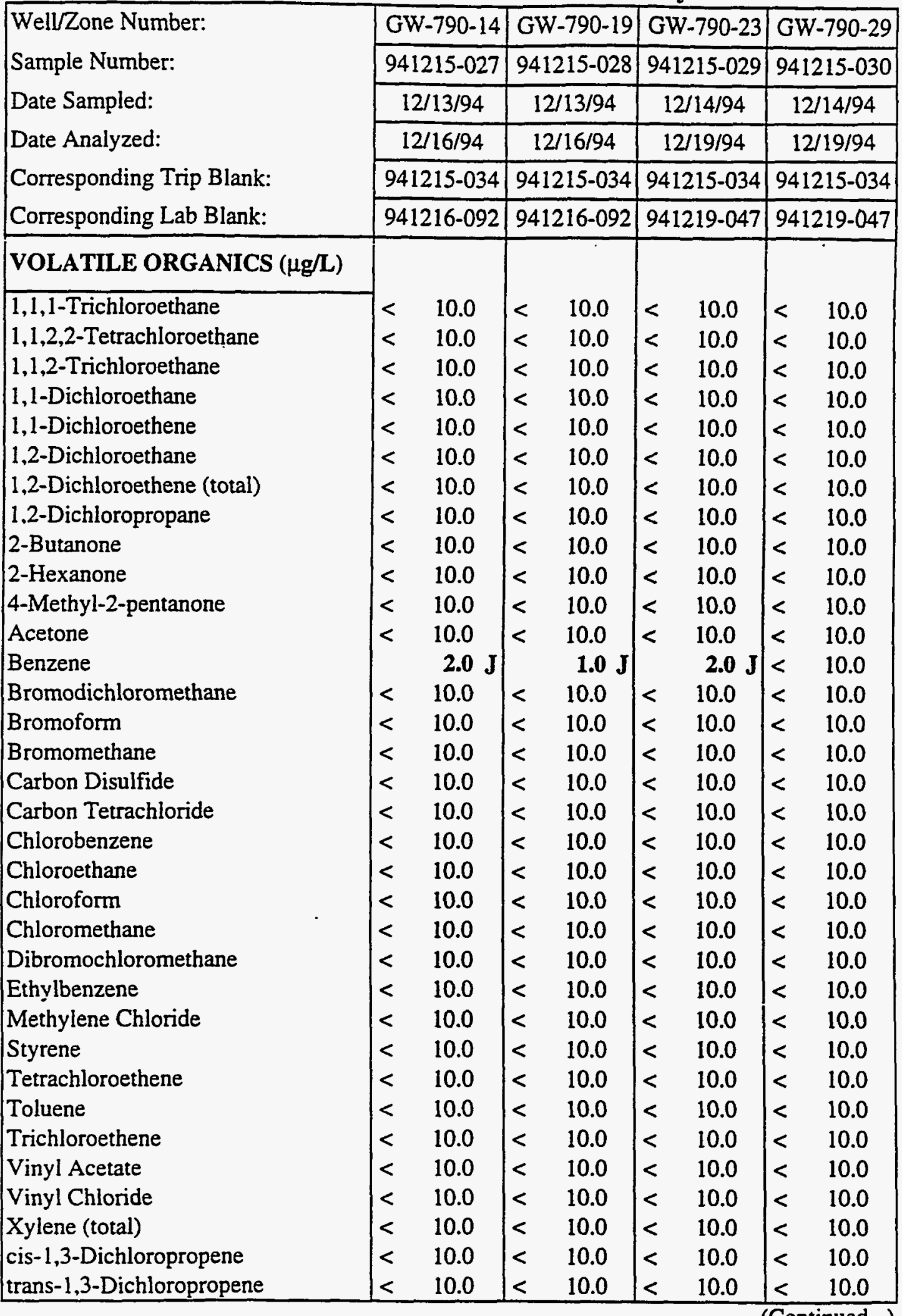


GW-790 VOC Analytical Results

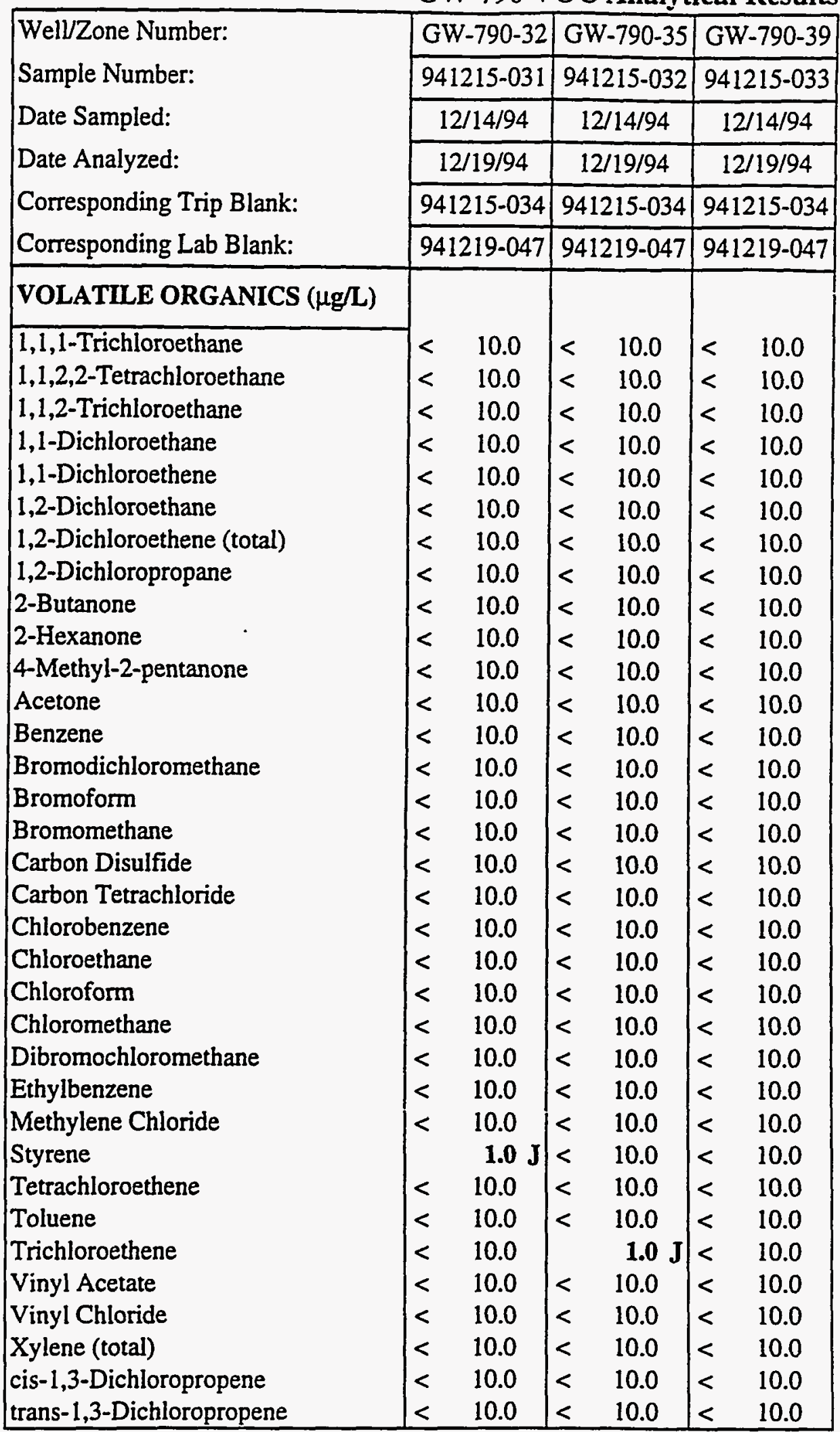


Appendix D

TRACE METAL ANALYTICAL RESULTS. 
Trace Metal Analytical Results

\begin{tabular}{|c|c|c|c|c|c|c|c|c|c|c|c|c|c|}
\hline Well/Zone Number: & & \multicolumn{2}{|l|}{ GW-790-2 } & \multicolumn{2}{|l|}{ GW-790-5 } & \multicolumn{2}{|l|}{ GW-790-7 } & \multicolumn{2}{|c|}{ GW-790-10 } & \multicolumn{2}{|c|}{ GW-790-14 } & \multirow{2}{*}{\multicolumn{2}{|c|}{ GW-790-19 }} \\
\hline Date Sampled: & & $4 / 23 / 95$ & & $4 / 23 / 95$ & & $4 / 23 / 95$ & & $4 / 23 / 95$ & & $12 / 13 / 94$ & & & \\
\hline METALS (mg/L) & $\begin{array}{c}\text { Background } \\
\text { Screening } \\
\text { levels* }\end{array}$ & & & & & & & & & & & & \\
\hline Aluminum & 7.9 & 2.0 & d) & 0.49 & & $<0.4$ & d & $<0.4$ & d & $<0.2$ & d & $<0.2$ & d) \\
\hline Antimony & 0.05 & $<5.0$ & d) & $<1.0$ & d & $<1.0$ & d & $<1.0$ & d. & $<0.5$ & d) & $<0.5$ & d \\
\hline Arsenic & & 5.0 & d) & $<1.0$ & d) & $<1.0$ & d & $<1.0$ & d & $<0.5$ & d & $<0.5$ & d \\
\hline Barium & & 220.0 & & 5.4 & & 5.4 & & 8.7 & & 1.2 & & 0.56 & \\
\hline Beryllium & 0.0019 & $<\quad 0.03$ & d) & $<0.006$ & d) & $<0.006$ & d) & $<0.006$ & d) & $<0.003$ & d) & $<0.003$ & d \\
\hline Boron & 0.57 & 0.4 & d) & 0.15 & & 0.19 & & 0.32 & & 0.32 & & 0.36 & \\
\hline Cadmium & 0.005 & $<0.3$ & d) & $<0.06$ & d & $<0.06$ & d & $<0.06$ & d] & $<0.03$ & d) & $<0.03$ & d) \\
\hline Chromium & & 10.0 & & $<0.2$ & d) & $<0.2$ & d) & $<0.2$ & d) & $<0.1$ & d) & $<0.1$ & d \\
\hline Cobalt & 0.025 & $<0.5$ & d & $<0.1$ & d & $<0.1$ & d & $<0.1$ & d & $<0.05$ & d & $<0.05$ & d \\
\hline Copper & 0.3 & $<0.4$ & d) & $<0.08$ & d) & $<0.08$ & d) & $<0.08$ & d & $<0.04$ & d) & $<0.04$ & d) \\
\hline Iron & 13.0 & 70.0 & & 0.23 & & 0.96 & & 0.56 & & $<0.05$ & d) & $<0.05$ & d) \\
\hline Lead & 0.05 & $<5.0$ & d & $<1.0$ & d) & $<1.0$ & d) & $<1.0$ & d & $<0.5$ & d) & $<0.5$ & d) \\
\hline Lithium & & 5.1 & & 1.1 & & 1.2 & & 1.6 & & 0.77 & & 0.57 & \\
\hline Manganese & 2.7 & 8.0 & & 0.18 & & 0.18 & & 0.17 & & 0.029 & & 0.017 & \\
\hline Molybdenum & 0.01 & $<\quad 1.0$ & d & $<0.2$ & d & $<0.2$ & d) & $<0.2$ & d & $<0.1$ & d) & $<0.1$ & d) \\
\hline Nickel & 0.33 & 12.0 & & $<0.2$ & d) & $<0.2$ & d & $<0.2$ & d & $<0.1$ & d & $<0.1$ & d) \\
\hline Selenium & & 5.0 & d & $<1.0$ & d & $<1.0$ & d) & $<1.0$ & d & $<0.5$ & d & $<0.5$ & d \\
\hline Silver & & 0.6 & d & $<0.12$ & d) & $<0.12$ & d) & $<0.12$ & d) & $<0.06$ & d & $<0.06$ & d) \\
\hline Strontium & 0.83 & 980.0 & & 26.0 & & 34.0 & & 63.0 & & 4.7 & & 1.5 & \\
\hline Thorium & 0.2 & $<20.0$ & d & $<4.0$ & d] & $<4.0$ & d) & $<4.0$ & d & $<2.0$ & d & $<2.0$ & d) \\
\hline Vanadium & 0.058 & $<0.5$ & l & $<0.1$ & d & $<0.1$ & d) & $<0.1$ & d & $<0.05$ & d & $<0.05$ & d \\
\hline Zinc & 0.079 & 0.36 & & $<\quad 0.04$ & d & 0.2 & & 0.18 & & 0.19 & & $<0.02$ & d) \\
\hline Dilution factor & & 100 & & 20 & & 20 & & 20 & & 10 & & 10 & \\
\hline
\end{tabular}

* Background screening levels obtained from HSW Environmental Consultants, 1994. Levels listed are for ORR Aquitards. Where blank, there is no background screening level listed.

** italicized values show a detection limit that is above the recommended background screening level.

*** bold face values show levels that are above the detection limit and the background screening level. 
Trace Metal Analytical Results

\begin{tabular}{|c|c|c|c|c|c|c|}
\hline Well/Zone Number: & & GW-790-23 & GW-790-29 & GW-790-32 & GW-790-35 & GW-790-39 \\
\hline Date Sampled: & & $12 / 14 / 94$ & $12 / 14 / 94$ & $12 / 14 / 94$ & $12 / 14 / 94$ & $12 / 14 / 94$ \\
\hline METALS (mg/L) & $\begin{array}{c}\text { Background } \\
\text { Screening } \\
\text { levels* }\end{array}$ & & & & & \\
\hline Aluminum & 7.9 & 0.021 & 0.032 & $<0.02$ & 0.03 & $<0.02$ \\
\hline Antimony & 0.05 & $<0.05$ & $<0.05$ & $<0.05$ & $<0.05$ & $<0.05$ \\
\hline Arsenic & & $<0.05$ & $<0.05$ & $<0.05$ & $<0.05$ & $<0.05$ \\
\hline Barium & & 0.043 & 0.044 & 0.052 & 0.092 & 0.031 \\
\hline Beryllium & 0.0019 & $<0.0003$ & $<0.0003$ & $<0.0003$ & $<0.0003$ & $<0.0003$ \\
\hline Boron & 0.57 & 0.91 & 2.1 & 2.0 & 0.084 & 0.18 \\
\hline Cadmium & 0.005 & $<0.003$ & $<0.003$ & $<0.003$ & $<0.003$ & $<0.003$ \\
\hline Chromium & & $<0.01$ & $<0.01$ & $<0.01$ & $<0.01$ & $<0.01$ \\
\hline Cobalt & 0.025 & $<0.005$ & $<0.005$ & $<0.005$ & $<0.005$ & $<0.005$ \\
\hline Copper & 0.3 & $<0.004$ & $<0.004$ & $<0.004$ & $<0.004$ & $<0.004$ \\
\hline Iron & 13.0 & 0.038 & 0.068 & 0.033 & 0.09 & 0.032 \\
\hline Lead & 0.05 & $<0.05$ & $<0.05$ & $<0.05$ & $<0.05$ & $<0.05$ \\
\hline Lithium & & 0.15 & 0.18 & 0.14 & 0.005 & 0.007 \\
\hline Manganese & 2.7 & 0.0016 & $<0.0011$ & $<0.0016$ & $<0.0038$ & 0.011 \\
\hline Molybdenum & 0.01 & 0.02 & $<0.01$ & $<0.01$ & $<0.01$ & $<0.01$ \\
\hline Nickel & 0.33 & $<0.01$ & $<0.01$ & $<0.01$ & $<0.01$ & $<0.01$ \\
\hline Selenium & & $<0.05$ & $<0.05$ & $<0.05$ & $<0.05$ & $<0.05$ \\
\hline Silver & & $<0.006$ & $<0.006$ & $<0.006$ & $<0.006$ & $<0.006$ \\
\hline Strontium & 0.83 & 0.12 & 0.1 & 0.22 & 0.18 & 0.033 \\
\hline Thorium & 0.2 & $<0.2$ & $<0.2$ & $<0.2$ & $<0.2$ & $<0.2$ \\
\hline Vanadium & 0.058 & $<0.005$ & $<0.005$ & $<0.005$ & $<0.005$ & 0.005 \\
\hline Zinc & 0.079 & 0.022 & 0.021 & $\begin{array}{r}0.017 \\
\end{array}$ & 0.034 & 0.0027 \\
\hline \multicolumn{2}{|l|}{ Dilution factor } & 1 & 1 & 1 & 1 & 1 \\
\hline
\end{tabular}

* Background screening levels obtained from HSW Environmental Consultants, 1994. Levels listed are for ORR Aquitards. Where blank, there is no background screening level listed.

** italicized values show a detection limit that is above the recommended background screening level.

*** bold face va'ues show levels that are above the detection limit and the background screening level. 
Appendix E

MAJOR ANIONS AND CATIONS AND FIELD PARAMETERS. 
Major Anions and Cations and Field Parameters.

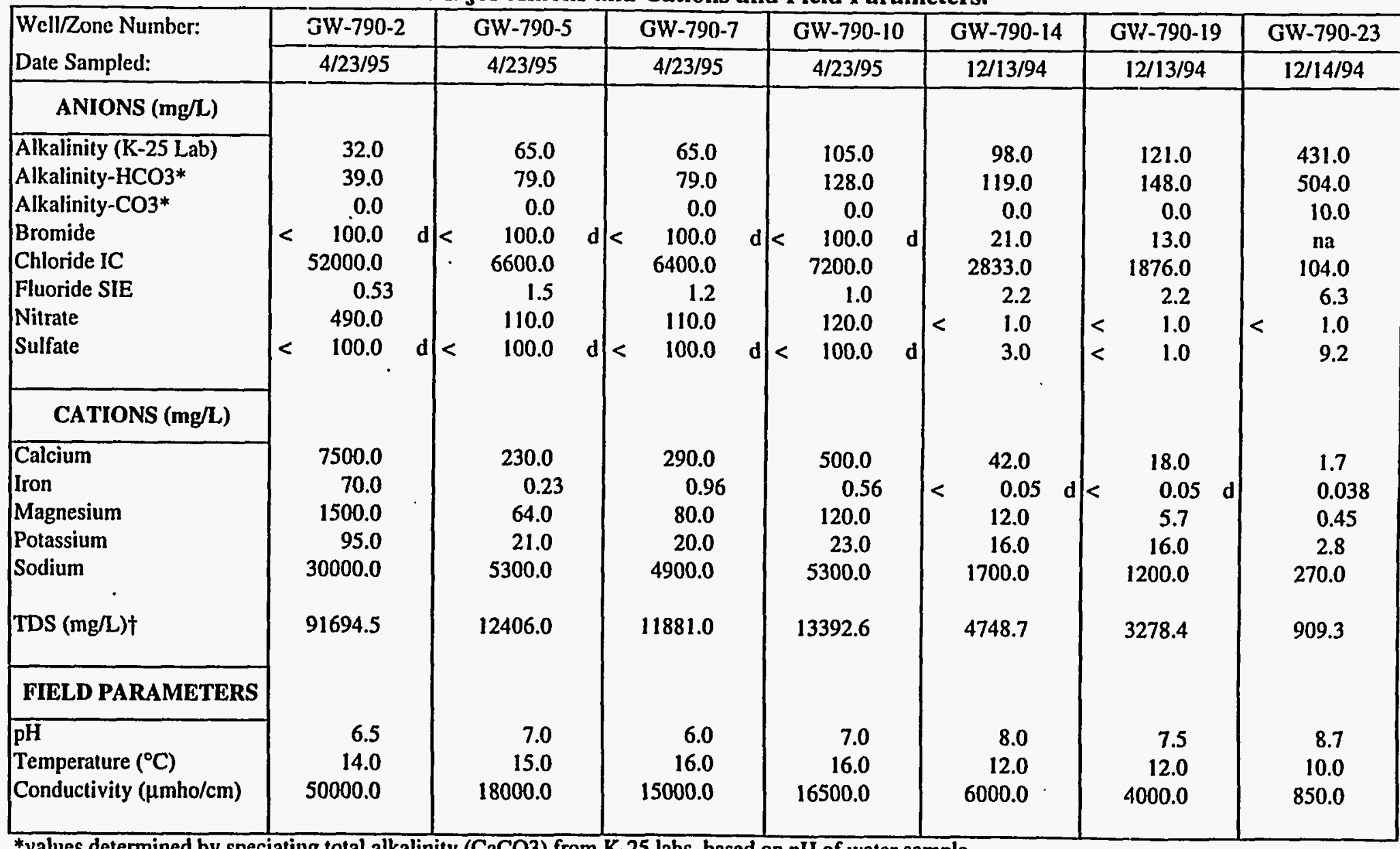

*values determined by speciating total alkalinity (CaCO3) from $\mathrm{K}-25$ labs, based on pH of water sample.

tSum of major anions and cations ( $\mathrm{mg} / \mathrm{L})$.

$\mathrm{d}=$ indicates sample diluted for analysis.

na $=$ not analyzed 
Major Anions and Cations and Field Parameters.

\begin{tabular}{|c|c|c|c|c|}
\hline Well/Zone Number: & GW-790-29 & GW-790-32 & GW-790-35 & GW-790-39 \\
\hline Date Sampled: & $12 / 14 / 94$ & $12 / 14 / 94$ & $12 / 14 / 94$ & $12 / 14 / 94$ \\
\hline ANIONS (mg/L) & & & & \\
\hline $\begin{array}{l}\text { Alkalinity (K-25 Lab) } \\
\text { Alkalinity-HCO3* } \\
\text { Alkalinity-CO3* } \\
\text { Bromide } \\
\text { Chloride IC } \\
\text { Fluoride SIE } \\
\text { Nitrate } \\
\text { Sulfate }\end{array}$ & $\begin{array}{r}131.0 \\
695.0 \\
7.0 \\
\text { na } \\
12.0 \\
6.0 \\
<\quad 1.0 \\
41.0\end{array}$ & $\begin{array}{r}333.0 \\
517.0 \\
0.0 \\
\mathrm{na} \\
16.0 \\
4.9 \\
<\quad 1.0 \\
13.0\end{array}$ & $\begin{array}{r}789.0 \\
240.0 \\
0.0 \\
\mathrm{na} \\
15.0 \\
0.1 \\
68.0 \\
25.0\end{array}$ & $\begin{array}{c}749.0 \\
79.0 \\
0.0 \\
\text { na } \\
16.0 \\
0.5 \\
1.5 \\
1.0\end{array}$ \\
\hline CATIONS (mg/L) & \multirow[b]{2}{*}{$\begin{array}{c}1.2 \\
0.068 \\
0.47 \\
2.1 \\
280.0\end{array}$} & & & \\
\hline $\begin{array}{l}\text { Calcium } \\
\text { Iron } \\
\text { Magnesium } \\
\text { Potassium } \\
\text { Sodium }\end{array}$ & & $\begin{array}{l}2.4 \\
0.033 \\
1.2 \\
2.7 \\
200.0\end{array}$ & $\begin{array}{c}71.0 \\
0.09 \\
19.0 \\
1.9 \\
11.0\end{array}$ & $\begin{array}{l}5.3 \\
0.032 \\
7.7 \\
3.0 \\
18.0\end{array}$ \\
\hline TDS (mg/L) $\dagger$ & \multirow[t]{2}{*}{1045.2} & \multirow[t]{2}{*}{757.2} & \multirow[t]{2}{*}{451.3} & \multirow[t]{2}{*}{131.3} \\
\hline FIELD PARAMETERS & & & & \\
\hline $\begin{array}{l}\mathrm{pH} \\
\text { Temperture }\left({ }^{\circ} \mathrm{C}\right) \\
\text { Conductivity }(\mu \mathrm{mho} / \mathrm{cm})\end{array}$ & $\begin{array}{r}8.5 \\
12.0 \\
890.0\end{array}$ & $\begin{array}{r}8.0 \\
13.0 \\
600.0\end{array}$ & $\begin{array}{r}7.0 \\
14.0 \\
410.0\end{array}$ & $\begin{array}{r}7.5 \\
13.5 \\
140.0\end{array}$ \\
\hline
\end{tabular}

*values determined by speciating total alkalinity $(\mathrm{CaCO} 3)$ from $\mathrm{K}-25$ labs, based on $\mathrm{pH}$ of water sample.

† Sum of major anions and cations ( $\mathrm{mg} / \mathrm{L})$.

$d=$ indicates sample diluted for analysis.

na $=$ not analyzed 
Appendix F

\section{CHARGE BALANCE CALCULATIONS.}


Charge Balance Calculations

\begin{tabular}{|c|c|c|c|c|c|}
\hline Well/Zone Number: & GW-790-23 & GW-790-29 & GW-790-32 & GW-790-35 & GW-790-39 \\
\hline Date Sampled: & $12 / 14 / 94$ & $12 / 14 / 94$ & $12 / 14 / 94$ & $12 / 14 / 94$ & $12 / 14 / 94$ \\
\hline ANIONS (meq்/L) & & & & & \\
\hline $\begin{array}{l}\text { Alkalinity-HCO3 } \\
\text { Alkalinity-CO3 } \\
\text { Bromide } \\
\text { Chloride IC } \\
\text { Fluoride SIE } \\
\text { Nitrate } \\
\text { Sulfate IC }\end{array}$ & $\begin{array}{l}8.3 \\
0.3 \\
0.0 \\
2.9 \\
0.3 \\
0.0 \\
0.2\end{array}$ & $\begin{array}{r}11.4 \\
0.2 \\
0.0 \\
0.3 \\
0.3 \\
0.0 \\
0.9\end{array}$ & $\begin{array}{l}8.5 \\
0.0 \\
0.0 \\
0.5 \\
0.3 \\
0.0 \\
0.3\end{array}$ & $\begin{array}{l}3.9 \\
0.0 \\
0.0 \\
0.4 \\
0.0 \\
1.1 \\
0.5\end{array}$ & $\begin{array}{l}1.3 \\
0.0 \\
0.0 \\
0.5 \\
0.0 \\
0.0 \\
0.0\end{array}$ \\
\hline Total Anions & 12.1 & 13.1 & 9.5 & 6.0 & 1.8 \\
\hline CATIONS (meq/L) & & & & & \\
\hline \begin{tabular}{|l} 
Calcium \\
Iron \\
Magnesium \\
Potassium \\
Sodium
\end{tabular} & $\begin{array}{r}0.1 \\
0.0 \\
0.0 \\
0.1 \\
11.7\end{array}$ & $\begin{array}{r}0.1 \\
0.0 \\
0.0 \\
0.1 \\
12.2\end{array}$ & $\begin{array}{l}0.1 \\
0.0 \\
0.1 \\
0.1 \\
8.7\end{array}$ & $\begin{array}{l}3.5 \\
0.0 \\
1.6 \\
0.0 \\
0.5\end{array}$ & $\begin{array}{l}0.3 \\
0.0 \\
0.6 \\
0.1 \\
0.8\end{array}$ \\
\hline Total Cations & 11.9 & 12.3 & 9.0 & 5.6 & 1.8 \\
\hline$\overline{\text { CHARGE BALANCE (\%) }}$ & -1 & -3 & -3 & -3 & -1 \\
\hline
\end{tabular}


Charge Balance Calculations

\begin{tabular}{|c|c|c|c|c|c|c|}
\hline Well/Zone Number: & GW-790-2 & GW-790-5 & GW-790-7 & GW-790-10 & GW-790-14 & GW-790-19 \\
\hline Date Sampled: & $4 / 23 / 95$ & $4 / 23 / 95$ & $4 / 23 / 95$ & $4 / 23 / 95$ & $12 / 13 / 94$ & $12 / 13 / 94$ \\
\hline \multicolumn{7}{|l|}{ ÁNIONS (meq/L) } \\
\hline Alkalinity-HCO3 & 0.6 & 1.3 & 1.3 & 2.1 & 2.0 & 2.4 \\
\hline Alkalinity-CO3 & 0.0 & 0.0 & 0.0 & 0.0 & $0 . \dot{0}$ & 0.0 \\
\hline Bromide & 0.0 & 0.0 & 0.0 & 0.0 & 0.3 & 0.2 \\
\hline Chloride IC & 1466.6 & 186.1 & 180.5 & 203.1 & 79.9 & 52.9 \\
\hline Fluoride SIE & 0.0 & 0.1 & 0.1 & 0.1 & 0.1 & 0.1 \\
\hline Nitrate & 7.9 & 1.8 & 1.8 & 1.9 & 0.0 & 0.0 \\
\hline Sulfate IC & 0.0 & 0.0 & 0.0 & 0.0 & 0.1 & 0.0 \\
\hline Total Anions & 1475.1 & 189.3 & 183.6 & 207.1 & 82.3 & 55.6 \\
\hline \multicolumn{7}{|l|}{ CATIONS (meq/L) } \\
\hline Calcium & 374.3 & 11.5 & 14.5 & 25.0 & 2.1 & 0.9 \\
\hline Iron & 3.8 & 0.0 & 0.1 & 0.0 & 0.0 & 0.0 \\
\hline Magnesium & 123.4 & 5.3 & 6.6 & 9.9 & 1.0 & 0.5 \\
\hline Potassium & 2.4 & 0.5 & 0.5 & 0.6 & 0.4 & 0.4 \\
\hline Sodium & 1304.5 & 230.5 & 213.1 & 230.5 & 73.9 & 52.2 \\
\hline Total Cations & 1808.3 & 247.8 & 234.7 & 265.9 & 77.4 & 54.0 \\
\hline CHARGE BALANCE (\%) & 10 & 13 & 12 & 12 & -3 & -2 \\
\hline
\end{tabular}




\section{DISTRIBUTION}

1. L. V. Asplund

2. A. J. Caldanaro

3-9. R. B. Dreier

10. T. O. Early

11. J. A. Hodgins

12. D. D. Huff

13. G. K. Jacobs

14. W. K. Jago

15. S. B. Jones

16. H. L. King

17-18. A. K. Lee/OSTI

19. D. M. Matteo

20. G. R. Moline

21. H. C. Newsom

22-23. P. T. Owen

24. E. Owens

25-29. C. T. Rightmire

30. S. H. Stowe

31. L. E. Toran

32. D. B. Watson

33. C. S. Walker

34-38. ER Document Management Center-RC

39. J. A. Archer, Jacobs Engineering, 125 Broadway, Oak Ridge, TN 37830

40. K. Black, EC Corporation, 10511 Hardin Valley Rd., Knoxville, TN 37932

41. P. Hofmann, DOE-ORO, P. O. Box 2001, Oak Ridge, TN 37831

42. B. H. Keuper, Queen's University Department of Engineering, Kingston, Ontario, Canada KJL 3N6

43. L. A. Shevenell, Nevada Bureau of Mines and Geology, MS 178, Reno, NV 89557-0088

44. D. Moss, SAIC, 800 Oak Ridge Tumpike, P. O. Box 2502, Oak Ridge, TN 37831

45. J. Walker, HSW, 687 Emory Valley Rd., Suite B, Oak Ridge, TN 37830 